\title{
Concentrate supplementation of a diet based on medium-quality grass silage for 4 weeks prepartum: Effects on cow performance, health, metabolic status, and immune function
}

\author{
M. W. Little,${ }^{*} \dagger^{1}$ N. E. O’Connell, $†$ M. D. Welsh, † F. J. Mulligan, $\S$ and C. P. Ferris ${ }^{*}$ \\ ${ }^{*}$ Sustainable Agri-Food Sciences Division, Agri-Food and Biosciences Institute, Large Park, Hillsborough, BT26 6DR, United Kingdom \\ †School of Biological Sciences, Institute for Global Food Security, Queen's University Belfast, 18-30 Malone Road, Belfast, BT9 5BN, United \\ Kingdom \\ $\ddagger$ Veterinary Sciences Division, Agri-Food and Biosciences Institute, Stoney Road, Belfast, BT4 3SD, United Kingdom \\ $\S$ School of Veterinary Medicine, University College Dublin, Belfield, Dublin 4, Ireland
}

\begin{abstract}
Because negative energy balance (EB) contributes to transition-period immune dysfunction in dairy cows, dietary management strategies should aim to minimize negative EB during this time. Prepartum diets that oversupply energy may exacerbate negative EB in early lactation, with detrimental effects on immune function. However, with lower body condition score (BCS) cows, it has been shown that offering concentrates in addition to a grass silage-based diet when confined during an 8-wk dry period resulted in increased neutrophil function in early lactation. The aim of this study was to examine if similar benefits occur when concentrate feeding was restricted to a 4 -wk period prepartum. Twenty-six multiparous and 22 primiparous Holstein-Friesian cows were offered ad libitum access to medium-quality grass silage until 28 d before their predicted calving dates (actual mean of $32 \mathrm{~d}$ prepartum; standard deviation $=$ 6.4). At this time multiparous cows had a mean BCS of 2.9 (standard deviation $=0.12$ ) and primiparous cows a mean BCS of 3.0 (standard deviation $=0.14$ ) on a 1 to 5 scale. Cows were then allocated in a balanced manner to 1 of 2 treatments (13 multiparous cows and 11 primiparous cows on each treatment): silage only ( $\mathrm{SO}$ ) or silage plus concentrates $(\mathrm{S}+\mathrm{C})$ until calving. Cows on SO were offered the same grass silage ad libitum. Cows on $\mathrm{S}+\mathrm{C}$ were offered an ad libitum mixed ration of the same grass silage and additional concentrates in a 60:40 dry matter (DM) ratio, which provided a mean concentrate DM intake (DMI) of $4.5 \mathrm{~kg} /$ cow per d. After calving, all cows were offered a common mixed ration (grass silage and concentrates, 40:60 DM ratio) for $70 \mathrm{~d}$ postpartum. Offering concentrates in addition
\end{abstract}

Received August 1, 2016.

Accepted December 13, 2016.

${ }^{1}$ Corresponding author: mark.little@afbini.gov.uk to grass silage during the $4 \mathrm{wk}$ prepartum increased prepartum DMI (12.0 versus $10.1 \mathrm{~kg} /$ cow per d), EB $(+40.0$ versus $+10.6 \mathrm{MJ} /$ cow per $\mathrm{d})$, and body weight (BW; 640 versus $628 \mathrm{~kg}$ ), and tended to increase BCS (3.02 versus 2.97). However, postpartum DMI, milk yield, milk composition, BW change, BCS change, serum nonesterified fatty acid, and $\beta$-hydroxybutryrate concentrations, health, and corpus luteum measures were unaffected by treatment. The in vitro assays of neutrophil phagocytosis, neutrophil oxidative burst, and interferon gamma production, conducted on blood samples obtained at d 14 prepartum and d 3, 7, 14, and 21 postpartum, were unaffected by treatment. Primiparous cows had higher phagocytic fluorescence intensity at d 14 prepartum and $d 3$ and 7 postpartum; a higher percentage of neutrophils undergoing oxidative burst at d 3, 7, and 21 postpartum; and a higher oxidative burst fluorescence intensity at d 14 prepartum and d 7, 14, and 21 postpartum compared with multiparous cows. This suggests that neutrophil function of primiparous cows was less sensitive to the changes occurring during the transition period than that of multiparous cows. In conclusion, offering concentrates during the 4-wk period prepartum had no effect on postpartum DMI, milk yield, body tissue mobilization, EB, measures of neutrophil or lymphocyte function, health, or corpus luteum activity.

Key words: dairy cow, transition period, immunity, metabolic status

\section{INTRODUCTION}

The transition period is commonly defined as the last $3 \mathrm{wk}$ of gestation and the first $3 \mathrm{wk}$ of lactation (Grummer, 1995; Drackley, 1999). During this time the dairy cow experiences an immune dysfunction, which is an important contributing factor toward health problems, which peak in incidence immediately postpartum (Ingvartsen, 2006; Mulligan and Doherty, 2008). 
Both prepartum and postpartum negative energy balance (EB) have been shown to impair aspects of peripartum neutrophil activity and increase the risk of postpartum uterine disease (Hammon et al., 2006; Galvão et al., 2010), with this due in part to the individual metabolites associated with negative EB. Low serum glucose concentrations has been shown to have detrimental effects on neutrophil function (Galvão et al., 2010), high nonesterified fatty acid (NEFA) concentrations decreased peripheral blood mononuclear cell proliferation and neutrophil respiratory burst activity (Ster et al., 2012), and high BHB concentrations impaired neutrophil chemotaxis (Suriyasathaporn et al., 2000) and respiratory burst (Hoeben et al., 1997). Indeed, elevated NEFA and BHB concentrations have been shown to be predictive of infectious diseases, such as clinical mastitis (Moyes et al., 2009) and metritis (Ospina et al., 2010). Thus, it is suggested that prepartum nutritional strategies should seek to minimize negative EB and provide for good metabolic status during the transition period.

Increasing the energy density of the prepartum diet is one approach by which prepartum EB can be improved, and indeed the NRC (2001) advocates a higher energy density in the close-up dry cow diet. However, the suitability of this approach is likely to be influenced by cow BCS at drying off. Offering higher energy TMR diets for the entire prepartum period (in cows with a BCS $>3.2$ at study commencement; scale 1 to 5) resulted in greater body tissue mobilization postpartum (Janovick and Drackley, 2010), and decreased prepartum neutrophil phagocytosis (Graugnard et al., 2012), compared with those offered lower energy rations. Similarly, increasing energy allowance during the last few weeks prepartum (in cows with a mean BCS of 3.2 to 3.5 at study commencement; scale 1 to 5) resulted in a greater degree of negative EB postpartum (Hayirli et al., 2011), higher incidence of subclinical ketosis postpartum (Vickers et al., 2013), and higher serum NEFA concentrations postpartum (Zhang et al., 2015). Thus, when an increased energy allowance is offered to prepartum cows that already are in high BCS, or when this increased energy allowance results in a high BCS, detrimental consequences may ensue.

When exposed to the typical grassland-based dairy production systems of Western Europe, higher yielding cows may complete the lactation with a BCS of 3.0 or less (scale 1 to 5 ). For example, in an on-farm study by Law et al. (2016) involving over 1,200 cows, $88 \%$ of cows had a BCS $\leq 2.5$ (scale 1 to 5 ) at drying off. In these scenarios it is possible that concentrate feeding during the dry period will have beneficial effects on subsequent health and performance, but without the risk of cows becoming overconditioned. A recent study involving low BCS cows (2.4 at study commencement; scale 1 to 5), found that offering $3 \mathrm{~kg}$ concentrates for 8 wk prepartum in addition to a grass silage-based diet improved EB prepartum and led to improved neutrophil phagocytic index at wk 1 postpartum, compared with unsupplemented cows (Little et al., 2016). However, as concentrates are considerably more expensive than conserved forages (Finneran et al., 2012), it is important to identify if similar benefits can be achieved with a shorter period of concentrate feeding.

It was hypothesized that offering additional concentrates to low BCS cows during the prepartum period would have a beneficial effect on immunity during the transition period, and on postpartum performance. Therefore, the objectives of the current study were to examine the effects of offering lower BCS cows a concentrate supplement, in addition to grass silage, during the $4 \mathrm{wk}$ prepartum on cow performance, health, fertility, metabolites, and neutrophil and lymphocyte functions.

\section{MATERIALS AND METHODS}

\section{Animals and Housing}

This study involved 28 multiparous (mean parity, 3.3; $\mathrm{SD}=1.7$ ) and 22 primiparous (first-calving heifers) Holstein-Friesian dairy cows. Cows had a mean predicted transmitting ability for milk yield and fat plus protein yield of $99(\mathrm{SD}=190.4)$ and $16.2(\mathrm{SD}=10.61)$ $\mathrm{kg}$, respectively, and a mean profitable lifetime index of $£ 186(\mathrm{SD}=83.7)$. These cows were within the top $1 \%$ of UK genetics in terms of profitable lifetime index. All procedures described in this paper were approved by the animal research ethics committee at the Agri-Food and Biosciences Institute, Hillsborough, and conducted under an experimental license granted by the Department of Health, Social Services and Personal Safety for Northern Ireland in compliance with the United Kingdom Animals (Scientific Procedures) Act (1986).

Throughout the experiment (except at calving) cows were housed in a freestall cubicle house with concrete flooring, which was scraped every $3 \mathrm{~h}$ by an automated system. The cubicle to cow ratio was $\geq 1: 1$ at all times, thus meeting the recommendations of the Farm Animal Welfare Council (1997). Cubicles were fitted with rubber mats and were bedded 3 times each week with sawdust.

\section{Experimental Design, Diets, and Feeding}

Multiparous cows were dried off 8 wk before the predicted calving date (mean dry-off date, January 20, 2015; SD = $11 \mathrm{~d}$ ), with primiparous cows joining 
Table 1. Diet ingredients (\% DM) and concentrate ingredients ( $\mathrm{g} / \mathrm{kg}$ fresh basis) offered during the prepartum and postpartum periods

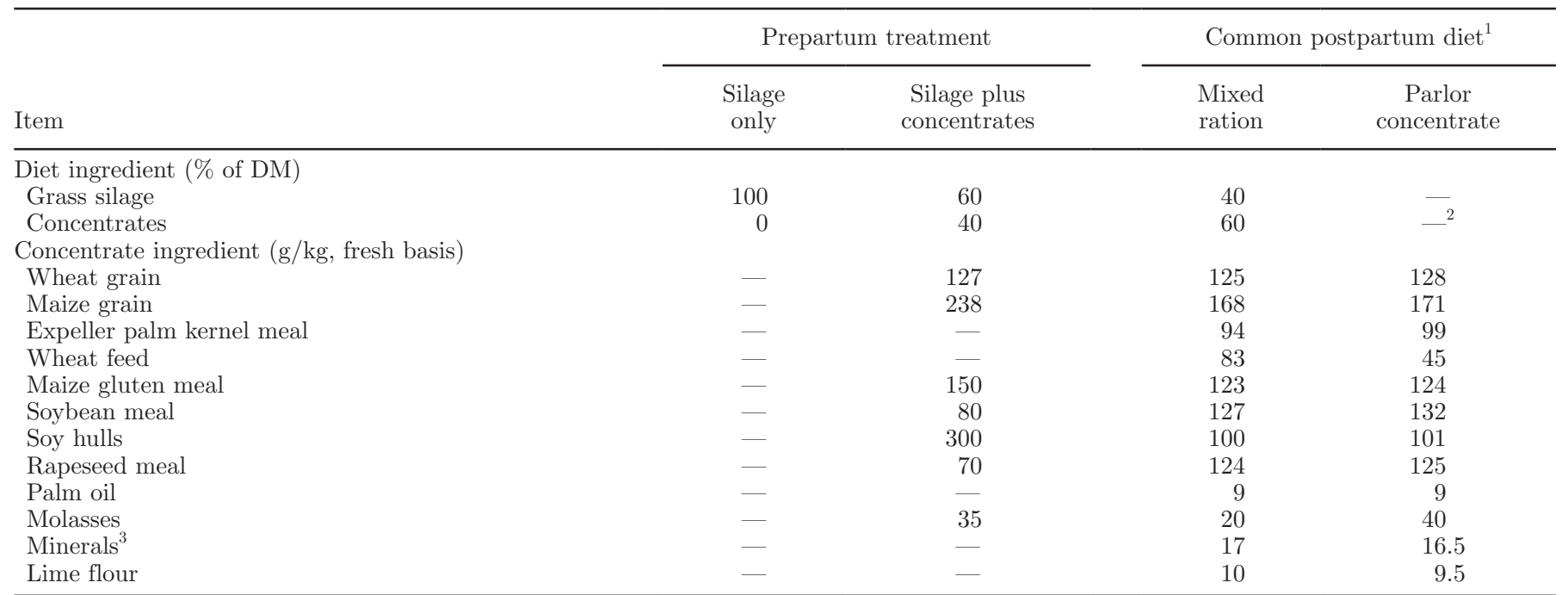

${ }^{1}$ Common diet offered with both treatments.

${ }^{2}$ In-parlor concentrates were offered at $1.0 \mathrm{~kg} / \mathrm{d}$ at d 1 postpartum, increasing at a rate of $0.5 \mathrm{~kg} / \mathrm{d}$, so that multiparous cows were offered 5.0 $\mathrm{kg} / \mathrm{d}$ at d 9 postpartum onward, and primiparous cows were offered $4.0 \mathrm{~kg} / \mathrm{d}$ at d 7 postpartum onward.

${ }^{3}$ Contained a minimum of $29 \% \mathrm{Ca}, 2 \% \mathrm{P}, 5 \% \mathrm{Mg}, 2 \% \mathrm{Na}, 1,400 \mathrm{mg} / \mathrm{kg}$ of Cu, $16 \mathrm{mg} / \mathrm{kg}$ of Se, $400 \mathrm{kIU} / \mathrm{kg}$ of vitamin A, $80 \mathrm{kIU} / \mathrm{kg}$ of vitamin $\mathrm{D}_{3}$, and $1,400 \mathrm{IU} / \mathrm{kg}$ of vitamin E (Trouw Nutrition, Cheshire, UK).

the group at this stage. At this time multiparous cows had a mean BCS of 2.8 , assessed using a 1 to 5 scale (Edmonson et al., 1989; multiparous cows had a mean BCS of 2.7, $\mathrm{SD}=0.19$; primiparous cows had a mean BCS of 2.9, SD =0.10). All cows were offered ad libitum access to a diet consisting of medium-quality grass silage until $28 \mathrm{~d}$ before the predicted calving date, to which a prepartum mineral/vitamin mix (containing a minimum of $1 \% \mathrm{Ca}, 5 \% \mathrm{P}, 18 \% \mathrm{Mg}, 13 \% \mathrm{Na}, 3,000$ $\mathrm{mg} / \mathrm{kg}$ of $\mathrm{Cu}, 45 \mathrm{mg} / \mathrm{kg}$ of Se, $450 \mathrm{kIU} / \mathrm{kg}$ of vitamin $\mathrm{A}, 120 \mathrm{kIU} / \mathrm{kg}$ of vitamin $\mathrm{D}_{3}, 8,000 \mathrm{IU} / \mathrm{kg}$ of vitamin E; Trouw Nutrition, Cheshire, UK) was included to achieve a target intake of $100 \mathrm{~g} / \mathrm{cow}$ per $\mathrm{d}$. At this stage, multiparous had a mean BCS of $2.9(\mathrm{SD}=0.12)$, and primiparous cows a mean BCS of $3.0(\mathrm{SD}=0.14)$, and were then randomly assigned to 1 of 2 treatments, silage only $(\mathbf{S O})$ and silage plus concentrate $(\mathbf{S}+\mathbf{C})$, with these 2 experimental treatments implemented until the time of calving, including the time spent in the maternity pen. To ensure cows on each treatment were balanced, randomization was restricted to the following factors: expected calving date, BW and BCS at $8 \mathrm{wk}$ precalving, and predicted transmitting ability for fat plus protein yield $(\mathrm{kg})$. Previous lactation $305-\mathrm{d}$ milk yield, parity, number of services during the previous lactation, and expected calving interval were also taken into account when allocating multiparous cows.

Cows on SO $(\mathrm{n}=25)$ continued to be offered ad libitum access to the medium-quality grass silage for the final 4 wk prepartum (actual mean of $32 \mathrm{~d}$ prepartum;
$\mathrm{SD}=7 \mathrm{~d})$. Cows on $\mathrm{S}+\mathrm{C}(\mathrm{n}=25)$ were offered ad libitum access to a mixed diet consisting of the same medium-quality grass silage plus concentrates (mixed in a 60:40 DM ratio), which was designed to provide an average concentrate intake of approximately 5.0 $\mathrm{kg} /$ cow per $\mathrm{d}$. The ingredient composition of the prepartum concentrate offered is presented in Table 1. In addition to the mineral/vitamin mix described earlier, during this 4 -wk period cows on both treatments were supplemented with Calcined Magnesite (Trouw Nutrition, Cheshire, UK), which was included in the ration to achieve a target intake of $50 \mathrm{~g} / \mathrm{cow}$ per day.

The grass silage offered to both treatments was produced from a primary growth herbage, which was harvested from perennial ryegrass-dominated swards and ensiled following a 24- to 48-h period of field wilting. Rations were prepared daily using a complete diet mixer wagon (Redrock Varicut, Redrock, County Armagh, Northern Ireland). The experimental diets for each treatment were transferred directly from the mixer wagon to feed boxes mounted on weigh cells, access to which was controlled by a Calan Gate feeding system (American Calan Inc., Northwood, NH) linked to an electronic identification system, thus enabling individual cow intakes to be recorded daily. Cows within each treatment group were able to feed from several feed boxes, whereas a feed box to cow ratio of $\geq 1: 3$ was maintained at all times. Both diets were offered ad libitum at $107 \%$ of the previous daily intake. The uneaten ration was removed daily at approximately 
$0800 \mathrm{~h}$, whereas the fresh ration was offered between 0900 and $1000 \mathrm{~h}$.

Cows were moved to a straw bedded maternity pen 24 to $48 \mathrm{~h}$ before their expected calving, based on physical observations. Postcalving (normally within 12 to $24 \mathrm{~h}$ ), cows were moved from the maternity pen to the milking cow accommodation described earlier, with all cows offered ad libitum access to a common mixed diet, which consisted of grass silage and concentrates (in a 40:60 DM ratio) via the Calan gate feeding system. Cows were also offered additional concentrates at each milking via in-parlor feeders, starting at $1.0 \mathrm{~kg} / \mathrm{d}$ on $\mathrm{d} 1$ postpartum, increasing in $0.5 \mathrm{~kg} / \mathrm{d}$ increments, so that multiparous cows were offered $5.0 \mathrm{~kg} / \mathrm{d}$ and primiparous cows were offered $4.0 \mathrm{~kg} / \mathrm{d}$ for the duration of the study. The ingredient compositions of the concentrates offered in the mixed ration and in the parlor are presented in Table 1. The grass silage offered was produced from a primary growth herbage, which was harvested from predominately perennial ryegrassdominated swards (harvest date, June 7) and ensiled following a 24- to 48-h period of field wilting. Cows remained on this diet until d 70 of lactation (end of study).

\section{Feed Analysis}

Samples of grass silage were taken daily (prepartum $\mathrm{n}=98$, postpartum $\mathrm{n}=142$ ), dried at $85^{\circ} \mathrm{C}$ for $18 \mathrm{~h}$ to determine oven DM content, and milled through a sieve with $0.8 \mathrm{~mm}$ apertures. Subsamples of the dried milled silages were collected twice weekly and composited every $14 \mathrm{~d}$ (prepartum $\mathrm{n}=6$, postpartum $\mathrm{n}=10$ ), with the composited sample analyzed for NDF, ADF, and ash. In addition, a sample of the silage was taken every $7 \mathrm{~d}$ (prepartum, $\mathrm{n}=12$; postpartum, $\mathrm{n}=20$ ), split into 2 portions, 1 for analysis of $\mathrm{pH}$ and concentrations of gross energy, $\mathrm{CP}(\mathrm{N} \times 6.25)$, ammonia- $\mathrm{N}$, and fermentation acids (lactic and acetic acid), and 1 for estimation of ME concentration. Volatility coefficients were used to convert the oven DM contents of the grass silages offered to a volatile-corrected DM basis. A sample of the concentrates offered was taken every $7 \mathrm{~d}$, dried at $100^{\circ} \mathrm{C}$ for $24 \mathrm{~h}$ before milling through a $0.8 \mathrm{~mm}$ sieve, and composited every $14 \mathrm{~d}$ (prepartum $\mathrm{n}=6$, postpartum $\mathrm{n}=10$ ). A subsample was analyzed for $\mathrm{NDF}, \mathrm{ADF}$, ash, gross energy, and $\mathrm{CP}(\mathrm{N} \times 6.25)$ concentrations.

Concentrations of NDF and ADF were determined using a Fibertec analyzer (Fibertec FT122, Foss, Hillerød, Denmark) based on the method by Cushnahan and Gordon (1995), and ash concentrations were determined following combustion in a muffle furnace at $550^{\circ} \mathrm{C}$ for approximately $10 \mathrm{~h}$. Metabolizable energy concentration was estimated by near-infrared reflectance spectroscopy according to Park et al. (1998), and gross energy concentration was determined using a bomb calorimeter (Parr 6300 Bomb Calorimeter, Parr Instrument Co., Moline, IL). The $\mathrm{N}$ concentration was determined using the Kjeldahl method (Tecator Kjeltec Auto 2400/2460 Analyzer/Sampler System, Foss) and ammonia-N as described by Steen (1989). Lactic acid and acetic acid concentrations were determined using single column GLC equipped with a flame-ionization detector (Varian Star 3400 CX GC, Varian Inc., Palo Alto, CA). Volatility coefficients were applied according to Porter and Murray (2001). To compare energy density of rations, ME was calculated using the formula $\mathrm{NE}_{\mathrm{L}} \div \mathrm{K}_{\mathrm{L}}$ (the efficiency of ME use for lactation), with $\mathrm{K}_{\mathrm{L}}=0.64$, according to Dong et al. (2015), where 1 $\mathrm{MCal}=4.184 \mathrm{MJ}$.

\section{Measurements of Cow Performance}

Individual daily feed intakes were recorded using the intake recording system described earlier. At parturition, calving difficulty was recorded as follows: $1=$ unobserved/unassisted, 2 = assisted without mechanical puller, $3=$ assisted with mechanical puller, $4=$ veterinary assisted, and $5=$ calf delivered by cesarean section. Calves were weighed immediately after birth. Cows were milked twice daily, between 0530 and $0700 \mathrm{~h}$, and 1530 and $1700 \mathrm{~h}$, through a 50-point rotary milking parlor, and individual cow milk yields were automatically recorded. Mean daily milk yields were calculated and condensed to weekly averages, except during the 5 -d period after calving when milk production was weighed manually. Colostrum samples were collected during the first milking postpartum, centrifuged $(800 \times$ $g$ at $7^{\circ} \mathrm{C}$ for $10 \mathrm{~min}$ ) to remove fat, and stored at $-20^{\circ} \mathrm{C}$ until analyzed for IgG concentration using an ELISA kit (Bio-X Diagnostics, Jemelle, Belgium) per the manufacturer's instructions (http://www.biox.com/en/ bio-k-165-quantelisa-bovine-immunoglobulin-competition-p-278/), with samples being tested in duplicate. Milk samples were obtained once weekly from 2 consecutive milkings (am and pm separately) throughout the study, a preservative tablet added (Broad Spectrum Microtabs II, D and F Control Systems, Norwood, MA), and samples stored at $4^{\circ} \mathrm{C}$ until analyzed. Samples were analyzed for fat, protein, and lactose content by Fourier transform infrared spectroscopy using an infrared milk analyzer (Milkoscan, model FT 120, Foss UK Ltd., Warrington, UK) and a weighted milk composition subsequently calculated for each sampling occasion. In addition, a single milk sample was collected for progesterone analysis from each cow on 2 occasions each week (Monday and Thursday pm) until $60 \mathrm{~d}$ postpar- 
tum. Samples were preserved and stored as above (for a maximum of $3 \mathrm{wk}$ ) with progesterone concentrations subsequently determined using a competitive ELISA kit (Ridgeway Science Ltd., Gloucestershire, UK), as described by Sauer et al. (1986). On 1 occasion each month, samples from 2 consecutive milkings, bulked in proportion to yield, were collected and SCC measured (model CA3A4, Delta Instruments, Drachten, the Netherlands).

All individual cow health disorders and treatments were recorded daily throughout the study period. Clinical signs of mastitis included clots and abnormal milk. Any incidence of displaced abomasum, dilated cecum, decreased rumen motility, or diarrhea was recorded as digestive upset. Cow BW were recorded weekly during the prepartum period and twice daily following milking (using an automatic weigh scale) from calving until the end of the study. Body condition scores were recorded weekly during the prepartum and postpartum periods, using a 1 to 5 scale (Edmonson et al., 1989). After a 42-d voluntary waiting period, cows were inseminated $12 \mathrm{~h}$ after visual observation of estrus. With the exception of cows treated for uterine infections and follicular cysts, no other reproductive treatments were given until after d 60 postpartum.

The mean daily ME requirements and balances for each cow were calculated using the equations contained within Feed into Milk (Agnew et al., 2004), the current UK dairy cow rationing system, where daily mean EB ( $\mathrm{MJ} /$ cow per $\mathrm{d}$ ) was determined using the equation:

mean energy balance $=$
$\left\{\left(\mathrm{ME}_{\text {main }+ \text { milk }} \times \mathrm{BW}^{0.75}\right)+\left[\frac{(0.0013 \times \mathrm{BW})}{K_{m}}\right]+\mathrm{ME}_{c}-10\right\}-\mathrm{ME} i$,

where $\mathrm{ME}_{\text {main+milk }}$ is the $\mathrm{ME}$ required for maintenance and milk production (MJ/kg of metabolic weight), $\mathrm{BW}^{0.75}$ is metabolic BW, $K_{m}$ is the efficiency of utilization of ME for activity [calculated as $0.35 \times \mathrm{ME}(\mathrm{MJ}) /$ gross energy $(\mathrm{MJ})+0.503], \mathrm{ME}_{c}$ is the $\mathrm{ME}$ required for pregnancy ( $\mathrm{MJ} /$ cow per $\mathrm{d}$ ), and $\mathrm{ME} i$ is ME intake (MJ/cow per d). Data for mean daily milk yield, milk fat, protein and lactose concentrations, and mean BW were used in the calculations for the $\mathrm{EB}$ variables.

\section{Vaginal Mucus Score Evaluation}

A clinical examination of vaginal mucus was conducted at $\mathrm{d} 7,14,21$, and 28 ( $\pm 1 \mathrm{~d})$ postpartum, according to Williams et al. (2005). The cow's vulva was thoroughly cleaned using a disinfected paper towel and then dried. A clean lubricated gloved hand was then inserted through the vulva into the vaginal area. In each cow the lateral, dorsal, and ventral walls of the vagina and the external cervical os were palpated, and the mucus contents of the vagina withdrawn manually for examination. The vaginal mucus was assessed and scored by a single operator throughout the course of the study for color, proportion, and volume of pus, and a character score assigned as follows: (0) clear or translucent mucus; (1) mucus containing flecks of white or off-white pus; (2) $<50 \mathrm{~mL}$ of exudate containing $\leq 50 \%$ white or off-white mucopurulent material; and (3) $>50$ $\mathrm{mL}$ of exudate containing purulent material, usually white or yellow, but occasionally sanguineous. The vaginal mucus was also assessed for odor, and given a score 0 for normal odor or a score of 1 if a fetid odor was detected. If a cow had a mucus score of 3 (or an elevated body temperature concurrent with a mucus score of 2), and an odor assessment of 1 , intrauterine antibiotics were administered (Metricure, Intervet/ Schering-Plough Animal Health, Walton Manor, Walton, Milton Keynes, UK).

\section{Blood Measurements}

Blood Biochemistry. Blood samples were obtained from the coccygeal vein or artery of each cow (0830 to $1030 \mathrm{~h}$, before fresh feed was offered) at d 14 before the predicted calving date (actual mean of $18 \mathrm{~d}$ prepartum; $\mathrm{SD}=7 \mathrm{~d})$, and $\mathrm{d} 3,7,14,21,28$, and $70( \pm 1 \mathrm{~d})$ postpartum. Samples were collected into evacuated tubes (BD, Oxford, UK), which were either coated with a clot activator or fluoride oxalate. The blood samples were centrifuged $\left(1,800 \times g\right.$ at $17^{\circ} \mathrm{C}$ for $\left.30 \mathrm{~min}\right)$ to obtain serum (tubes with a clot activator) or plasma (fluoride oxalate tubes), which were separated and stored at $-20^{\circ} \mathrm{C}$ until analyzed. Plasma was analyzed for glucose concentrations, whereas serum was analyzed for albumin, BHB, NEFA, total protein, and urea concentrations. Serum globulin was calculated as the difference between total protein and albumin. Serum biochemistry analysis was carried out on a Randox Imola chemistry analyzer system (Randox, County Antrim, UK), using Randox reagent kits (Randox).

Neutrophil Phagocytic Measurements. Additional blood samples were collected in lithium heparin tubes at $\mathrm{d} 14$ before the predicted calving date and at $\mathrm{d} 3,7,14$, and 21 ( $\pm 1 \mathrm{~d})$ postpartum for the measurement of the in vitro phagocytic capacity of neutrophils. The test and control samples were analyzed in duplicate within $3 \mathrm{~h}$ of collection, using the Phagotest kit (Orpegen Pharma GmbH, Heidelberg, Germany). Fifty microliters of heperanized whole blood was placed on 
ice for $10 \mathrm{~min}$, to which $20 \mu \mathrm{L}$ of stabilized and opsonized fluorescein isothiocyanate-labeled Escherichia coli was added. The test samples were incubated in a water bath at $38.5^{\circ} \mathrm{C}$ for $10 \mathrm{~min}$ and the control samples remained on ice for $10 \mathrm{~min}$. At the end of incubation, phagocytosis was halted by placing all samples onto ice. One hundred microliters of quenching solution was added to samples to eliminate the fluorescence of nonphagocytosed $E$. coli bacteria. Cells were washed using $3 \mathrm{~mL}$ of wash solution, centrifuged $(250 \times g$ for $5 \mathrm{~min}$ at $4^{\circ} \mathrm{C}$ ), and supernatants aspirated twice. Cells were then re-suspended in $2 \mathrm{~mL}$ of lysing solution for $20 \mathrm{~min}$ at room temperature. After centrifugation and aspiration of supernatants to recover cells, these underwent another wash step with $3 \mathrm{~mL}$ of wash solution and centrifugation. The supernatants were resuspended in 100 $\mu \mathrm{L}$ of DNA-staining solution, and incubated on ice for $10 \mathrm{~min}$ in the dark before analysis by flow cytometry.

Neutrophil Oxidative Burst Measurements. The blood samples collected for neutrophil phagocytic activity were also used to evaluate the in vitro oxidative burst activity of neutrophils. The test and control samples were analyzed in duplicate within $6 \mathrm{~h}$ of collection, using the Phagoburst kit (Orpegen Pharma GmbH, Heidelberg, Germany). Fifty microliters of heparinized whole blood was placed on ice for $10 \mathrm{~min}$, to which $20 \mu \mathrm{L}$ of opsonized E. coli was added to each test sample and $20 \mu \mathrm{L}$ of wash solution was added to each control sample, before incubation in a water bath at $38.5^{\circ} \mathrm{C}$. Twenty microliters of Dihydrorhodamine 123 substrate was then added, the tubes were mixed thoroughly, before incubating for a further $10 \mathrm{~min}$ in a water bath at $38.5^{\circ} \mathrm{C}$. Two milliliters of lysing solution was added to samples and incubated for 20 min at room temperature, to stop the reaction and fix the cells simultaneously. After centrifugation and aspiration of supernatants to recover cells, these underwent a wash step with $3 \mathrm{~mL}$ of wash solution and centrifugation. The supernatants were resuspended in $100 \mu \mathrm{L}$ of DNAstaining solution, and incubated on ice for $10 \mathrm{~min}$ in the dark before analysis by flow cytometry.

Flow Cytometric Analysis. Whole blood flow cytometric analysis was performed on a Beckman Coulter FC 500 series flow cytometer (Beckman Coulter, London, UK), equipped with a $488 \mathrm{~nm}$ laser and $635 \mathrm{~nm}$ filter. Data were analyzed with Kaluza Flow Cytometric analysis software (Beckman Coulter). During data acquisition of phagocytic and oxidative burst assays, a live gate was set in the $530-\mathrm{nm}$ fluorescence histogram for those events having at least the same DNA content as diploid cells to exclude cell debris and bacterial aggregates. For all samples, 10,000 events were acquired. A gate identifying the neutrophil population was set using the forward and side scatter properties of these cells and the corresponding green fluorescence histogram (FL1) was analyzed. The control sample was used to set a threshold for fluorescence so that only 1 to $3 \%$ of the acquired events were positive. The number of events above this threshold was counted as the percentage of neutrophils actively carrying out phagocytosis or oxidative burst. The mean fluorescence intensity (MFI) correlates to the number of bacteria phagocytosed by each cell or mean oxidative burst activity by a single cell. The phagocytic or oxidative burst index is the percentage of active neutrophils multiplied by the fluorescence intensity.

Interferon Gamma Production. An additional blood sample was collected in a lithium heparin tube at d 14 before the predicted calving date and d 3, 7, 14, 21,28 , and $70( \pm 1 \mathrm{~d})$ postpartum, for the measurement of IFN- $\gamma$ production by stimulated peripheral blood mononuclear cells. Whole blood samples $(250 \mu \mathrm{L})$ were cultured (commencing within $3 \mathrm{~h}$ of collection) in triplicate using flat-bottom 96-well tissue culture plates, with $30 \mu \mathrm{L}$ of PBS and $30 \mu \mathrm{L}$ of $5 \mu \mathrm{g} / \mathrm{mL}$ of pokeweed mitogen (lectin from Phytolacca americana) in PBS. Plates were incubated for $24 \mathrm{~h}$ at $37^{\circ} \mathrm{C}$ and $5 \% \mathrm{CO}_{2}$, and then centrifuged $\left(2,000 \times g\right.$ at $18^{\circ} \mathrm{C}$ for $\left.15 \mathrm{~min}\right)$ to obtain supernatants, which were stored at $-20^{\circ} \mathrm{C}$ until analyzed. The concentration of IFN- $\gamma$ was then determined using an ELISA kit (Biopanda Reagents, Belfast, UK) with samples being tested in triplicate. The sample incubated with PBS was used as a negative control to look at the inherent IFN- $\gamma$ level and the sample incubated with pokeweed mitogen used as a positive stimulant of peripheral blood mononuclear cells to produce IFN- $\gamma$.

\section{Statistical Analysis}

Two multiparous cows were removed from the experiment (one due to a chronic displaced abomasum and one due to injury), and their data excluded from the statistical analysis, leaving 26 multiparous cows (13 on each treatment) and 22 primiparous cows (11 on each treatment). Data were analyzed using GenStat Version 16.2 (VSN International, Oxford, UK). Data describing mean treatment values (e.g., mean milk yield), data at single time points (e.g., prepartum serum and plasma biochemistry), and flow cytometer analysis of neutrophil activity were analyzed using ANOVA with treatment and parity (primiparous or multiparous) as factors. Where significant in the model, appropriate pre-experimental variables were included as co-variates when analyzing corresponding dependent variables (e.g., for multiparous cows, milk yield was analyzed with the addition of previous lactation 305-d milk yield in the model). Weekly data (e.g., mean daily total 
Table 2. Chemical composition (and SD) of grass silages and concentrates offered during the prepartum and postpartum periods

\begin{tabular}{|c|c|c|c|c|c|}
\hline Item & \multicolumn{2}{|c|}{ Prepartum } & \multicolumn{3}{|c|}{ Postpartum } \\
\hline Oven DM (g/kg) & $225(21.4)$ & $888(14.9)$ & $303(39.3)$ & $901(3.0)$ & $893(8.1)$ \\
\hline $\operatorname{VCODM}^{1}(\mathrm{~g} / \mathrm{kg})$ & $244(16.7)$ & - & $326(31.5)$ & - & - \\
\hline \multicolumn{6}{|l|}{ Composition of DM $(\mathrm{g} / \mathrm{kg})$} \\
\hline $\mathrm{CP}$ & $142(24.9)$ & $179(2.1)$ & $116(6.7)$ & $214(3.0)$ & $211(3.0)$ \\
\hline Lactic acid & $146(60.2)$ & - & $97(19.8)$ & - & - \\
\hline Acetic acid & $22.8(10.7)$ & - & $22.2(5.53)$ & - & - \\
\hline $\mathrm{ADF}$ & $344(26.5)$ & $211(27.1)$ & $294(14.3)$ & $152(7.1)$ & $167(9.6)$ \\
\hline $\mathrm{NDF}$ & $558(43.8)$ & $408(57.4)$ & $517(22.3)$ & $317(8.4)$ & $312(11.1)$ \\
\hline Ash & $95(5.2)$ & $59(3.9)$ & $98(10.1)$ & $74(2.5)$ & $75(2.1)$ \\
\hline
\end{tabular}

${ }^{1} \mathrm{VCODM}=$ volatile corrected oven DM.

${ }^{2}$ Predicted using near infrared reflectance spectroscopy.

${ }^{3}$ Calculated from standard values.

DMI) were analyzed using REML analysis. The mixed model used included the following terms as fixed effects: treatment + week + parity $+($ treatment $\times$ week $)+$ $($ parity $\times$ week $)+($ treatment $\times$ parity $)$. Cow $\times$ week was included in the random model, to which a power model (city block metric) covariance structure was applied, and pre-experimental variables were included in the mixed model where appropriate. Binomial data (e.g., vaginal mucus scores) were analyzed using generalized linear model regression analysis with the logit link function. The model included treatment as a term and significance was identified using chi-squared. Data describing vaginal mucous scores data were translated into one integer: $0=0,0 ; 1=1,0 ; 2=2,0 ; 3=3,0$; $4=2,1 ; 5=3,1$, and for analysis were grouped into 2 categories, $\leq 1$ and $>1$, whereas calving difficulty was grouped into 2 categories: 1 and $\geq 1$.

\section{RESULTS AND DISCUSSION}

The objective of the current study was to examine the effect of supplementing a grass silage-based diet with concentrates during the 4 wk prepartum on performance, fertility, health, metabolic status, and immune function of lower BCS cows. The chemical composition of the grass silages and concentrates offered are presented in Table 2. The grass silage offered prepartum was medium quality with acceptable fermentation characteristics, whereas the grass silage offered postpartum was good quality and well fermented. The prepartum diets supplied 107 and $132 \%$ of the mean ME requirements for the $\mathrm{SO}$ and $\mathrm{S}+\mathrm{C}$ treatments, respectively, over the last 4 wk of the prepartum period, based on the equations contained within Feed into Milk, the current UK dairy cow feed rationing system (Agnew et al., 2004). As few significant $(P<0.05)$ interactions were present between treatment and parity for the data presented in Tables 3, 4, 5, 6, 7, and 8, only the main effects are presented in these tables with the relevant interactions described in the text.

\section{Prepartum Intake, Energy Balance, and Body Tissue Changes}

Cows on $\mathrm{S}+\mathrm{C}$ consumed a mean of $4.5 \mathrm{~kg}$ concentrate $\mathrm{DM} / \mathrm{d}$ from the prepartum mixed diet (Table 3). Offering concentrates in addition to a grass silage-based diet during the 4 wk prepartum resulted in a higher prepartum total DMI $(P<0.001$; Figure 1a) and lower prepartum silage DMI $(P<0.001$; Table 3$)$, in agreement with others (Keady et al., 2001; McNamara et al., 2003b). Similarly, offering a more energy-dense TMR during the close-up prepartum period has also been shown to increase prepartum DMI compared with offering less energy-dense diets (Holcomb et al., 2001; Rabelo et al., 2003; Zhang et al., 2015). A treatment $\times$ parity interaction was present for total DMI prepartum $(P=0.014)$, with the respective values for cows and heifers being 11.2 and $8.9 \mathrm{~kg} /$ cow per d for $\mathrm{SO}$ and 15.0 and $10.0 \mathrm{~kg} /$ cow per $\mathrm{d}$ for $\mathrm{S}+\mathrm{C}$. This suggests that when prepartum DMI is not limited by the physical characteristics of the diet or rumen capacity, multiparous cows had a greater feed demand than primiparous cows. 
Table 3. Effects of concentrate supplementation for 4 wk prepartum on prepartum and postpartum DMI, milk yields, milk constituents, SCC, SCS, and mastitis incidence

\begin{tabular}{|c|c|c|c|c|}
\hline \multirow[b]{2}{*}{ Item } & \multicolumn{2}{|c|}{ Prepartum treatment } & \multirow[b]{2}{*}{$\mathrm{SED}^{1}$} & \multirow[b]{2}{*}{$P$-value } \\
\hline & $\begin{array}{c}\text { Silage } \\
\text { only }\end{array}$ & $\begin{array}{c}\text { Silage plus } \\
\text { concentrates }\end{array}$ & & \\
\hline \multicolumn{5}{|l|}{$\overline{\text { Prepartum } \mathrm{DMI}^{2} \text { (kg/cow per d) }}$} \\
\hline Concentrate & 0.0 & 4.5 & & \\
\hline Silage & 10.1 & 8.4 & 0.41 & $<0.001$ \\
\hline Total & 10.1 & 12.9 & 0.53 & $<0.001$ \\
\hline \multicolumn{5}{|l|}{ Postpartum $\mathrm{DMI}^{3}(\mathrm{~kg} /$ cow per d) } \\
\hline Concentrate & 9.5 & 9.4 & 0.23 & 0.714 \\
\hline Silage & 9.4 & 9.2 & 0.32 & 0.627 \\
\hline Total & 18.9 & 18.6 & 0.50 & 0.619 \\
\hline \multicolumn{5}{|l|}{ Yield $^{3}(\mathrm{~kg} /$ cow per d) } \\
\hline Milk & 33.2 & 33.5 & 1.00 & 0.785 \\
\hline Fat & 1.47 & 1.48 & 0.058 & 0.748 \\
\hline Protein & 1.07 & 1.09 & 0.031 & 0.523 \\
\hline \multirow{2}{*}{\multicolumn{5}{|c|}{ Milk composition ${ }^{3}(\mathrm{~g} / \mathrm{kg})$}} \\
\hline & & & & \\
\hline Fat & 44.6 & 44.2 & 1.30 & 0.696 \\
\hline Protein & 32.8 & 33.1 & 0.51 & 0.541 \\
\hline \multirow{2}{*}{\multicolumn{5}{|c|}{$\begin{array}{l}\text { Lactose } \\
\text { Indicators of udder health }\end{array}$}} \\
\hline & & & & \\
\hline $\operatorname{SCC}^{3}(1,000 / \mathrm{mL})$ & 89 & 142 & - & - \\
\hline $\mathrm{SCS}^{4}$ & 10.8 & 11.0 & 0.30 & 0.636 \\
\hline Cows with clinical mastitis (\%) & 29 & 29 & 9.2 & $\mathrm{NA}^{5}$ \\
\hline \multicolumn{5}{|c|}{${ }^{1} \mathrm{SED}=$ standard error of the difference. } \\
\hline \multicolumn{5}{|c|}{${ }^{2}$ From 4 wk prepartum until the week of calving. } \\
\hline \multicolumn{5}{|c|}{${ }^{3}$ From calving until d 70 postpartum. } \\
\hline${ }^{4}$ Natural logarithm $\left(\log _{\mathrm{e}}\right)$ of SCC. & & & & \\
\hline
\end{tabular}

It is known that DMI may decline in the weeks preceding calving (Grummer, 1995), with this also demonstrated in the current study (Figure 1a). Total DMI with $\mathrm{SO}$ and $\mathrm{S}+\mathrm{C}$ averaged 10.1 and $12.0 \mathrm{~kg}$ during wk 4 prepartum, and 9.3 and $12.0 \mathrm{~kg}$ during wk 1 prepartum, respectively. This represents an $8 \%$ reduction in DMI across the 4 -wk period with the SO treatment ( $\mathrm{SO}$ energy density $\mathrm{ME}=11.7 \mathrm{MJ} / \mathrm{kg}$ ), much less than

Table 4. Effects of concentrate supplementation for 4 wk prepartum on prepartum and postpartum BW, BCS, and energy balance parameters

\begin{tabular}{|c|c|c|c|c|}
\hline \multirow[b]{2}{*}{ Item } & \multicolumn{2}{|c|}{ Prepartum treatment } & \multirow[b]{2}{*}{$\mathrm{SED}^{1}$} & \multirow[b]{2}{*}{$P$-value } \\
\hline & $\begin{array}{l}\text { Silage } \\
\text { only }\end{array}$ & $\begin{array}{l}\text { Silage plus } \\
\text { concentrates }\end{array}$ & & \\
\hline \multicolumn{5}{|l|}{$\overline{\text { Prepartum }^{2}}$} \\
\hline Mean BW (kg) & 628 & 640 & 3.3 & 0.001 \\
\hline BW change $(\mathrm{kg})$ & +22 & +34 & 4.7 & 0.027 \\
\hline Mean BCS & 2.97 & 3.02 & 0.028 & 0.060 \\
\hline BCS change & +0.07 & +0.15 & 0.034 & 0.027 \\
\hline Mean daily energy balance (MJ/cow per d) & +10.6 & +40.0 & 5.80 & $<0.001$ \\
\hline \multicolumn{5}{|l|}{ Postpartum $^{3}$} \\
\hline Mean BW (kg) & 565 & 570 & 9.1 & 0.654 \\
\hline BW change to nadir (kg) & -29.3 & -26.9 & 5.83 & 0.660 \\
\hline Days to nadir BW & 36 & 37 & 5.2 & 0.890 \\
\hline BW change to d $70(\mathrm{~kg})$ & -4.6 & -9.4 & 8.47 & 0.564 \\
\hline Mean BCS & 2.75 & 2.84 & 0.055 & 0.121 \\
\hline BCS change to d 70 & -0.27 & -0.37 & 0.068 & 0.130 \\
\hline Mean daily energy balance (MJ/cow per d) & -30.2 & -36.8 & 6.69 & 0.331 \\
\hline
\end{tabular}

${ }^{1} \mathrm{SED}=$ standard error of the difference.

${ }^{2}$ From 4 wk prepartum until the week of calving.

${ }^{3}$ From calving until d 70 postpartum. 
Table 5. Effects of concentrate supplementation for 4 wk prepartum on blood biochemistry parameters at d 14 before the expected calving date and during the first $70 \mathrm{~d}$ of lactation ${ }^{1}$

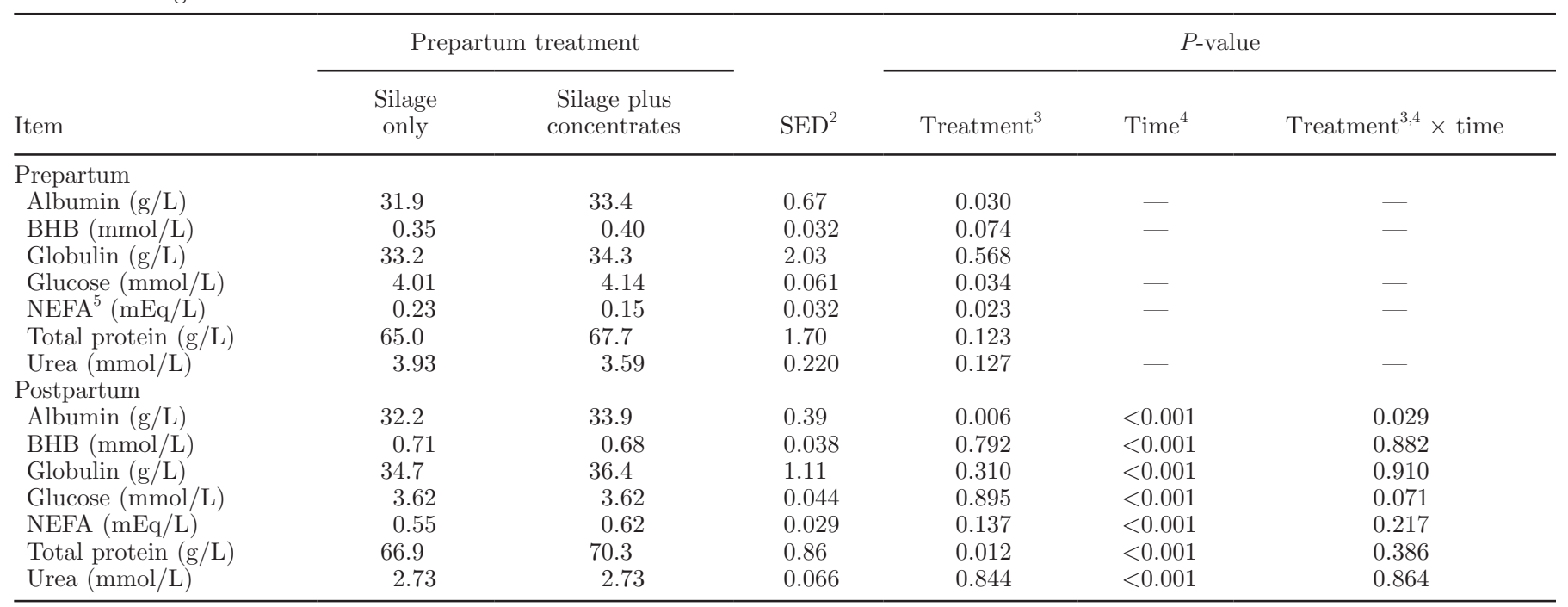

${ }^{1}$ The longitudinal response is detailed in Supplemental Table S1; https://doi.org/10.3168/jds.2016-11806.

${ }^{2} \mathrm{SED}=$ standard error of the difference.

${ }^{3}$ Prepartum treatment.

${ }^{4}$ Blood biochemistry was measured at a single time point $(18 \mathrm{~d})$ prepartum, so it was not possible to examine either time or treatment $\times$ time interaction.

${ }^{5} \mathrm{NEFA}=$ nonesterified fatty acid.

the $32 \%$ decline in DMI during the 3 wk preceding calving in a study compiled from results of 16 experiments using Holstein Friesian cows offered diets with an ME ranging from 8.3 to $10.9 \mathrm{MJ} / \mathrm{kg}$ (Hayirli et al., 2002). This reduction in total DMI was also less than that observed by Little et al. (2016) (25\% across $8 \mathrm{wk}$ prepartum, with the majority of the decline during the 4 wk preceding calving), when cows of similar genetic merit and production were offered a similar diet (grass silage energy density $\mathrm{ME}=10.5 \mathrm{MJ} / \mathrm{kg}$ ). Although the control of DMI in the prepartum cow is complex and multifactorial, with blood metabolites, hormones (Grummer et al., 2004), and nutritional and neurological mechanisms (Roche et al., 2013) influencing intakes, the high ME content of the silage offered may have contributed to the small DMI decline, perhaps a reflection of an increased digesta flow rate out of the rumen (Allen, 2000). In contrast, total DMI of cows on the $\mathrm{S}+\mathrm{C}$ treatment did not decrease between wk 4 prepartum and the week preceding calving (ME of diet $=$ $12.3 \mathrm{MJ} / \mathrm{kg}$ ). This is consistent with other studies that found concentrate supplementation of a grass silage diet

Table 6. Effects of concentrate supplementation for $4 \mathrm{wk}$ prepartum on the probability of obtaining a vaginal mucus score of $\leq 1$ or $>1$ at $\mathrm{d} 7,14,21$, and 28 of lactation

\begin{tabular}{lllll}
\hline & \multicolumn{2}{c}{ Mucus score } & & \\
\cline { 2 - 3 } Item & $\leq 1$ & $>1$ & SED $^{1}$ & $P$-value \\
\hline d 7 & 0.37 & 0.63 & & \\
$\quad$ Silage only & 0.17 & 0.83 & 0.087 & 0.101 \\
$\quad$ Silage plus concentrates & 0.29 & 0.71 & & \\
d 14 & 0.17 & 0.83 & 0.078 & 0.298 \\
$\quad$ Silage only & 0.58 & 0.42 & & \\
$\quad$ Silage plus concentrates & 0.54 & 0.46 & 0.100 & 0.771 \\
d 21 Silage only & & & \\
$\quad$ Silage plus concentrates & 0.83 & 0.17 & & \\
d 28 & 0.87 & 0.13 & 0.072 & 0.682 \\
$\quad$ Silage only & & & \\
Silage plus concentrates & &
\end{tabular}

${ }^{1} \mathrm{SED}=$ standard error of the difference. 
Table 7. Effects of concentrate supplementation for 4 wk prepartum on measures of corpus luteum activity (based on milk progesterone measurements) and on fertility treatments during the first $70 \mathrm{~d}$ of lactation

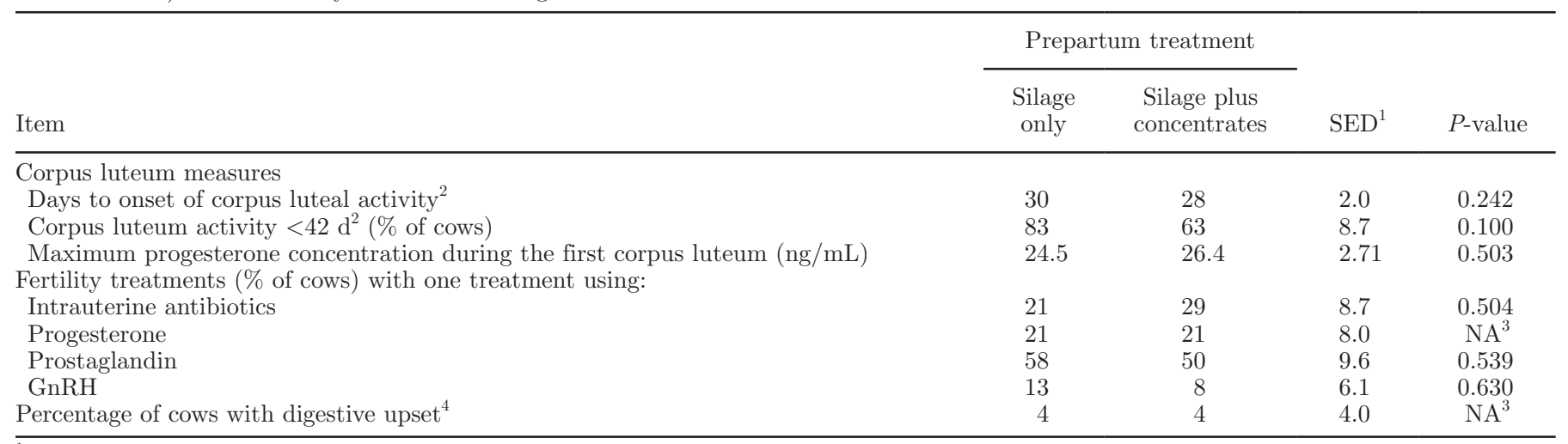

${ }^{1} \mathrm{SED}=$ standard error of the difference.

${ }^{2}$ Relative to calving date.

${ }^{3}$ No analysis possible as response is identical for both treatments.

${ }^{4}$ Percentage of cows with at least one incident.

abated the decline in total DMI that usually precedes calving (Keady et al., 2001; Little et al., 2016).

As a consequence of their higher prepartum intakes, cows on $\mathrm{S}+\mathrm{C}$ had a higher mean daily prepartum EB $(P<0.001$; Table 4) compared with those on SO. However, EB decreased with both treatments throughout the prepartum period $(P<0.001$; Figure $1 \mathrm{~d})$, and while cows on $\mathrm{S}+\mathrm{C}$ remained in positive $\mathrm{EB}$, those on $\mathrm{SO}$ entered negative EB during the week preceding calving. Prepartum negative EB has been associated with detrimental effects on peripartum neutrophil function (Hammon et al., 2006), and increased incidence of uterine (Kaneene et al., 1997) and production (Cameron et al., 1998) diseases, and consequently the $\mathrm{S}+\mathrm{C}$ treatment might have been expected to be associated with improved cow health; however, this was not the case in

Table 8. Effects of concentrate supplementation for 4 wk prepartum, and parity, on the mean percentage of phagocytic neutrophils, the mean fluorescence intensity (MFI) of phagocytic neutrophils, and the mean phagocytic index of neutrophils, at d 14 prepartum and d 3, 7, 14, and 21 postpartum

\begin{tabular}{|c|c|c|c|c|c|c|c|c|c|}
\hline Item & $\begin{array}{l}\text { Silage } \\
\text { only }\end{array}$ & $\begin{array}{l}\text { Silage plus } \\
\text { concentrates }\end{array}$ & $\mathrm{SED}^{1}$ & Primiparous & Multiparous & SED & Treatment & Parity & $\begin{array}{l}\text { Treatment } \\
\times \text { parity }\end{array}$ \\
\hline \multicolumn{10}{|l|}{ d 14 prepartum } \\
\hline$\%$ of phagocytic neutrophils & 42.4 & 40.5 & 2.10 & 40.5 & 42.2 & 2.11 & 0.374 & 0.423 & 0.463 \\
\hline $\mathrm{MFI}^{2^{2}}$ & 87.4 & 80.6 & 6.78 & 92.5 & 74.3 & 6.81 & 0.327 & 0.003 & 0.921 \\
\hline Phagocytic index ${ }^{3}$ & 37.1 & 32.5 & 3.51 & 38.9 & 31.3 & 3.52 & 0.197 & 0.038 & 0.705 \\
\hline MFI & 94.8 & 94.6 & 8.83 & 109.4 & 82.3 & 8.86 & 0.986 & 0.004 & 0.751 \\
\hline Phagocytic index & 43.6 & 43.2 & 4.76 & 51.2 & 36.8 & 4.78 & 0.941 & 0.004 & 0.637 \\
\hline \multicolumn{10}{|l|}{ d 7 postpartum } \\
\hline$\%$ of phagocytic neutrophils & 46.3 & 47.1 & 0.85 & 47.4 & 46.1 & 0.86 & 0.378 & 0.129 & 0.740 \\
\hline MFI & 92.5 & 101.6 & 8.28 & 111.4 & 84.9 & 8.31 & 0.280 & 0.003 & 0.555 \\
\hline Phagocytic index & 43.6 & 48.2 & 4.23 & 53.0 & 39.9 & 4.24 & 0.283 & 0.003 & 0.596 \\
\hline \multicolumn{10}{|l|}{ d 14 postpartum } \\
\hline$\%$ of phagocytic neutrophils & 46.2 & 46.0 & 0.92 & 45.8 & 46.4 & 0.92 & 0.780 & 0.571 & 0.219 \\
\hline MFI & 85.0 & 83.0 & 10.06 & 90.5 & 78.5 & 10.09 & 0.843 & 0.240 & 0.355 \\
\hline Phagocytic index & 39.9 & 38.5 & 5.04 & 42.3 & 36.6 & 5.06 & 0.784 & 0.269 & 0.281 \\
\hline
\end{tabular}

${ }^{1} \mathrm{SED}=$ standard error of the difference.

${ }^{2} \mathrm{MFI}(\times 1,000)$.

${ }^{3}$ Phagocytic index $=[(\%$ of phagocytic neutrophils $) \times(\mathrm{MFI})] / 100$. 
the current study. A treatment $\times$ parity interaction was present for mean EB during the 4 wk prepartum $(P=$ 0.042 ), with the respective values for cows and heifers being +20.0 and $-0.5 \mathrm{MJ} /$ cow per $\mathrm{d}$ for $\mathrm{SO}$ and +60.5 and $+15.6 \mathrm{MJ} /$ cow per $\mathrm{d}$ for $\mathrm{S}+\mathrm{C}$, with this reflecting the interaction for DMI described earlier.

Although both BW and BCS increased during the prepartum period as expected $(P<0.001$, Figure $1 \mathrm{~b}$ and 1c), the improved prepartum EB with cows on $\mathrm{S}+\mathrm{C}$ was reflected in a higher prepartum $\mathrm{BW}$ gain $(P$ $=0.027$; Table 4$)$, higher prepartum BW $(P=0.001)$, and a lower prepartum serum NEFA concentration $(P$ $=0.023$; Table 5), compared with those on SO. Whereas rumen fill effects due to higher total DMI (mean NDF intakes during the prepartum treatment period are 6.5 and $5.6 \mathrm{~kg} / \mathrm{d}$ for $\mathrm{S}+\mathrm{C}$ and $\mathrm{SO}$, respectively) may have contributed to the greater prepartum BW gain, cows on $\mathrm{S}+\mathrm{C}$ also tended to have a greater prepartum BCS gain $(P=0.027)$ and higher mean prepartum BCS $(P=0.060)$ over the 4 -wk period preceding calving. However, the magnitude of prepartum BCS gain in the current study was small, consistent with the findings of previous research which has demonstrated that cows offered grass silage-based diets, even when supplemented with concentrates, frequently gain little body condition during the dry period, especially during the late dry period (Keady et al., 2001; Law et al., 2011; Ingvartsen and Moyes, 2013). It is possible that some of the (a)

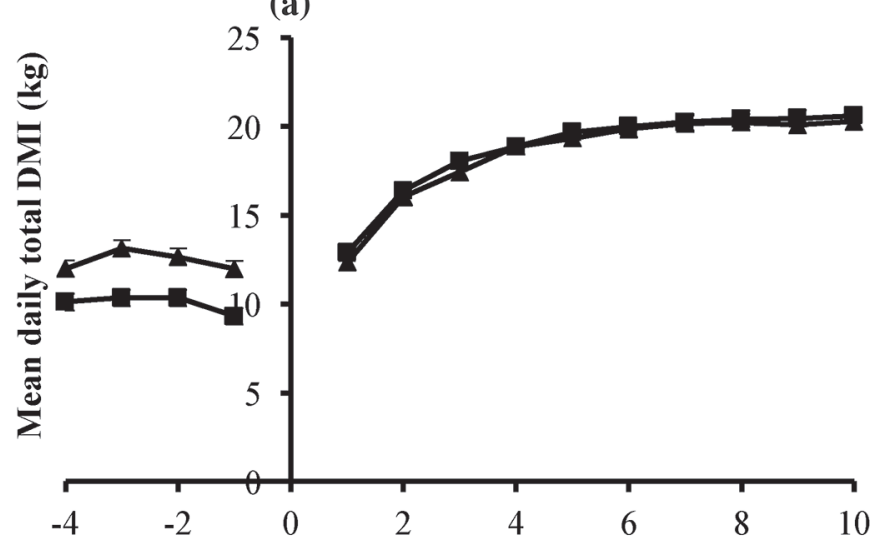

(c)

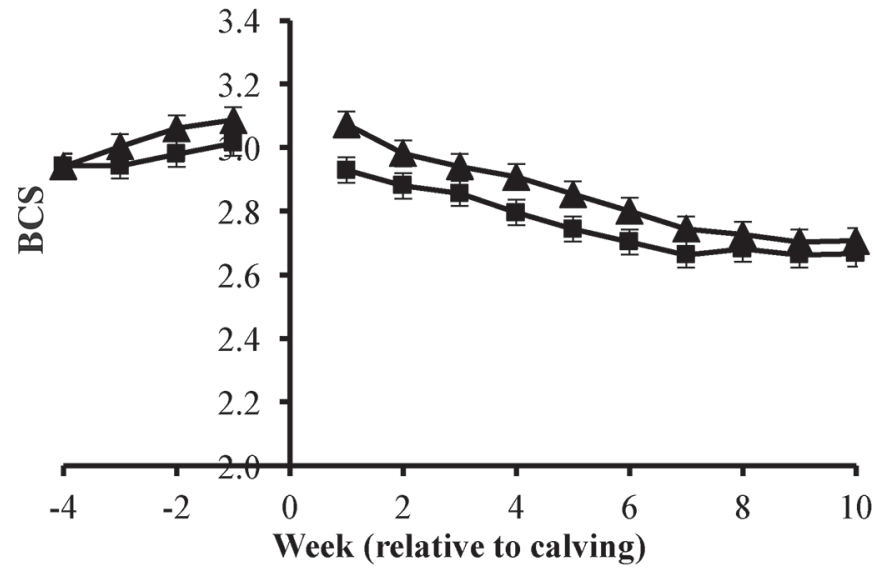

(b)

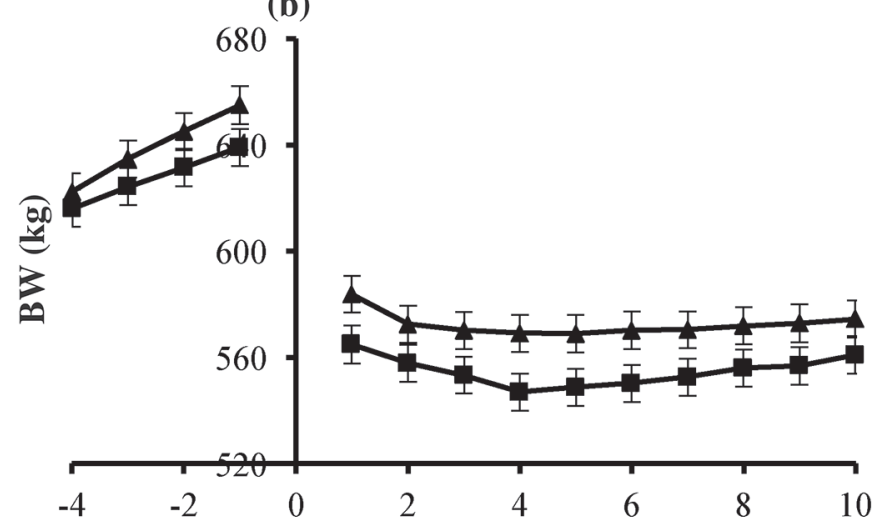

(d)

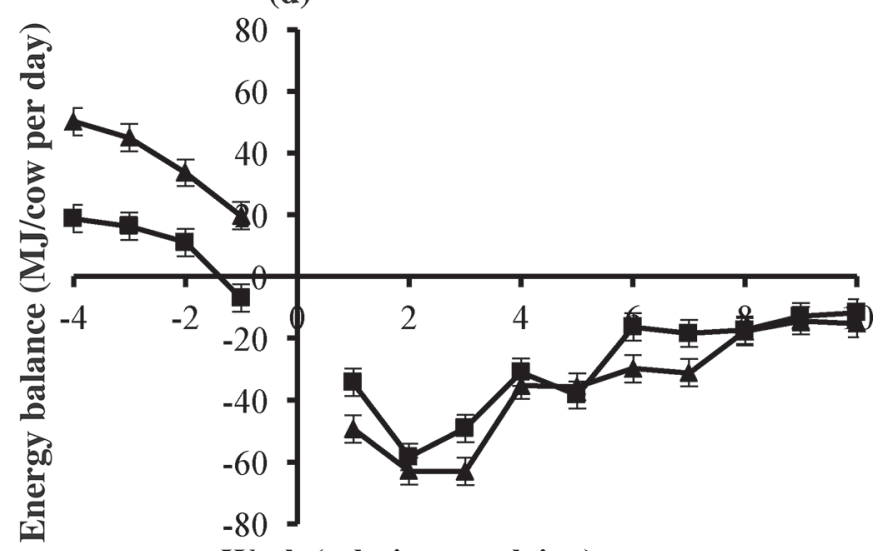

Week (relative to calving)

Figure 1. Effects of concentrate supplementation (black boxes, silage; black triangles, silage plus concentrates; error bars represent the SEM) for 4 wk prepartum, on prepartum and postpartum (a) total DMI (prepartum: treatment, SED $=0.56, P<0.001 ;$ time, SED $=0.28, P<0.001$; treatment $\times$ time, $\mathrm{SED}=0.54, P=0.120$; postpartum: treatment, $\mathrm{SED}=0.46, P=0.370$; time, $\mathrm{SED}=0.32, P<0.001 ;$ treatment $\times$ time, $\mathrm{SED}=0.55, P=0.896$, (b) BW (prepartum: treatment, $\mathrm{SED}=3.3, P<0.001$; time, $\mathrm{SED}=4.4, P<0.001$; treatment $\times$ time, $\mathrm{SED}=3.6, P=$ 0.246; postpartum: treatment, $\mathrm{SED}=9.2, P=0.741$; time, $\mathrm{SED}=2.7, P<0.001$; treatment $\times$ time, $\mathrm{SED}=7.0, P=0.625),(\mathrm{c}) \mathrm{BCS}(\mathrm{prepar}-$ tum: treatment, $\mathrm{SED}=0.03, P=0.068$; time, SED $=0.02, P<0.001$; treatment $\times$ time, $\mathrm{SED}=0.03, P=0.110$; postpartum: treatment, SED $=0.05, P=0.076$; time, $\mathrm{SED}=0.02, P<0.001$; treatment $\times$ time, $\mathrm{SED}=0.02, P=0.724)$ and $(\mathrm{d})$ mean weekly energy balance $($ prepartum: treatment, $\mathrm{SED}=8.07, P<0.001$; time, $\mathrm{SED}=10.71, P<0.001$; treatment $\times$ time, $\mathrm{SED}=7.09, P=0.563$; postpartum: treatment, $\mathrm{SED}=$ $6.32, P=0.221$; time, SED $=6.79, P<0.001$; treatment $\times$ time, SED $=10.42, P=0.654) . \mathrm{SED}=$ standard error of the differences of means 
additional energy consumed with the $\mathrm{S}+\mathrm{C}$ treatment may have been deposited as visceral adipose tissue, and that this was not reflected in large changes in BCS (Drackley et al., 2014). This may be particularly likely with lower BCS cows, as were used in the current study.

Although treatment had no effect $(P>0.1)$ on serum globulin, total protein, or urea concentrations prepartum (Table 5), cows on $\mathrm{S}+\mathrm{C}$ had a lower prepartum serum NEFA $(P=0.023)$ concentration, higher plasma glucose concentration $(P=0.034)$, and tended to have a higher prepartum serum BHB concentration $(P=$ 0.074) compared with cows on SO. As both serum NEFA and BHB concentrations are measures of adipose tissue mobilization (Otter, 2013), these 2 serum concentrations theoretically should be consistent. However, this discrepancy in serum NEFA and BHB concentrations preceding calving is consistent with McCarthy et al. (2015) who demonstrated a weak relationship between serum NEFA and BHB concentrations and concluded that a higher concentrations of one metabolite does not necessitate a higher concentration of the other.

\section{Calving Measures, Postpartum Intake, Milk Production, Body Tissue Changes, and Fertility}

Although calves born from cows on $\mathrm{S}+\mathrm{C}$ tended to be heavier than those born from cows on SO (39.6 vs. $42.4 \mathrm{~kg}, \mathrm{SED}=1.59, P=0.092)$, no effect was observed of prepartum diet on calving difficulty (probability of having a calving difficulty $>1$ is 0.21 and 0.33 for the $\mathrm{SO}$ and $\mathrm{S}+\mathrm{C}$ treatments, respectively; $\mathrm{SED}=0.86, P$ $=0.307$ ), in agreement with others (Flipot et al., 1988; McNamara et al., 2003b; Janovick and Drackley, 2010). The absence of an effect of prepartum diet on colostral IgG concentration $(54.3$ and $46.7 \mathrm{mg} / \mathrm{mL}$ for the $\mathrm{SO}$ and $\mathrm{S}+\mathrm{C}$ treatment, respectively; $\mathrm{SED}=5.20, P=$ $0.295)$ is in agreement with Nowak et al. (2012) and Dunn et al. (2016).

Offering additional concentrates during the close-up prepartum period did not affect postpartum DMI $(P$ $>0.1$; Table 3) as previously reported (Keady et al., 2001; Rabelo et al., 2003; Mann et al., 2015), whereas postpartum DMI increases with time from calving as expected $(P<0.001 ;$ Figure 1a). Although it is known that cows with a higher BCS at calving have a reduced postpartum DMI and mobilize more BCS in early lactation (Broster and Broster, 1998; Roche et al., 2009), the magnitude of difference in BCS between treatments at calving, although significant, was biologically small and therefore did not affect postpartum DMI. Thus the study provides no evidence that offering concentrates in late gestation prepares the rumen to better cope with the higher concentrate levels in early lactation diets, either through the enhancement of rumen papillae de- velopment (Dirksen et al., 1985) or the modification of the rumen microflora (Andersen et al., 1999). The absence of a milk yield or milk composition response to prepartum diet $(P>0.1$; Table 3$)$ is largely explained by the absence of a treatment effect on postpartum DMI, which is consistent with the findings of several other studies (Keady et al., 2001; Hayirli et al., 2011; Roche et al., 2015). In addition, given the similar postpartum DMI and yields of milk constituents within each treatment, it is unsurprising that postpartum EB was unaffected by treatment $(P>0.1$; Table 4$)$. The latter was reflected in the absence of an effect of treatment on postpartum BW and BCS $(P>0.1$; Table 4$)$, or serum NEFA and BHB concentrations $(P>0.1$; Table 5$)$. As expected, EB increased with time from calving $(P<$ 0.001; Figure 1d), along with decreases in serum BHB $(P<0.001$; Table 5$)$ and NEFA concentrations $(P<$ 0.001 ; Figure 1b). Although treatment had no effect $(P$ $>0.1$ ) on postpartum serum globulin, urea, or plasma glucose concentrations (Table 5), serum globulin, urea, and plasma glucose increased $(P<0.001)$ with time from calving, along with postpartum BW $(P<0.001$; Figure 1b) and postpartum BCS $(P<0.001$; Figure 1c). A treatment $\times$ time interaction was also observed with postpartum serum albumin $(P=0.029$; Table 5 and Supplemental Table S1; https://doi.org/10.3168/ jds.2016-11806), and a tendency was observed for a postpartum treatment $\times$ time interaction with glucose $(P=0.071$; Figure 2a). In contrast, others have reported that cows offered close-up diets with a higher energy density had a greater negative EB and body tissue mobilization postpartum (McNamara et al., 2003a; Hayirli et al., 2011; Roche et al., 2015) compared with cows offered a diet with lower energy density. However, the difference in BCS at calving between treatments in these published studies (0.2 BCS units, 1 to 5 scale; $3 \%$ difference in BCS change; 0.2 BCS, 1 to 10 scale; respectively) was similar to the current study (0.07 BCS units, 1 to 5 scale), which may be due to the lower BCS of cows in this study. A treatment $\times$ parity interaction was present for mean BW change postpartum $(P=$ $0.040)$, with the respective values for cows and heifers being +4.0 and $-14.7 \mathrm{~kg}$ for the SO treatment and -17.3 and $-0.1 \mathrm{~kg}$ for the $\mathrm{S}+\mathrm{C}$ treatment (Table 5).

Postpartum negative EB is known to negatively affect follicular development, interval to first ovulation, corpus luteum (CL) progesterone concentrations, and overall fertility (Butler, 2003). While prepartum EB was lower with cows on SO compared with those on $\mathrm{S}+\mathrm{C}$, postpartum EB was unaffected by treatment, consistent with treatments having no effect $(P>0.1)$ on days to onset of CL activity, percentage of cows with CL activity $<42 \mathrm{~d}$, maximum progesterone concentration associated with the first CL, or on the percentage 
of cows with at least one treatment with either progesterone, prostaglandin, or GnRH (Table 7). Similarly, Roche et al. (2015) found that prepartum feeding level did not affect the proportion of cows cycling, and Little et al. (2016) found CL measures to be unaffected when concentrates were supplemented throughout the entire prepartum period. Many other factors also influence reproductive performance in dairy cows, including the cow's ability to resolve the inevitable uterine infection that occurs postpartum. Uterine infection is known to have detrimental effects on reproductive performance, including abnormal progesterone profiles and delayed ovulation (Sheldon et al., 2008; Walsh et al., 2011). Whereas the response to uterine infection is regulated
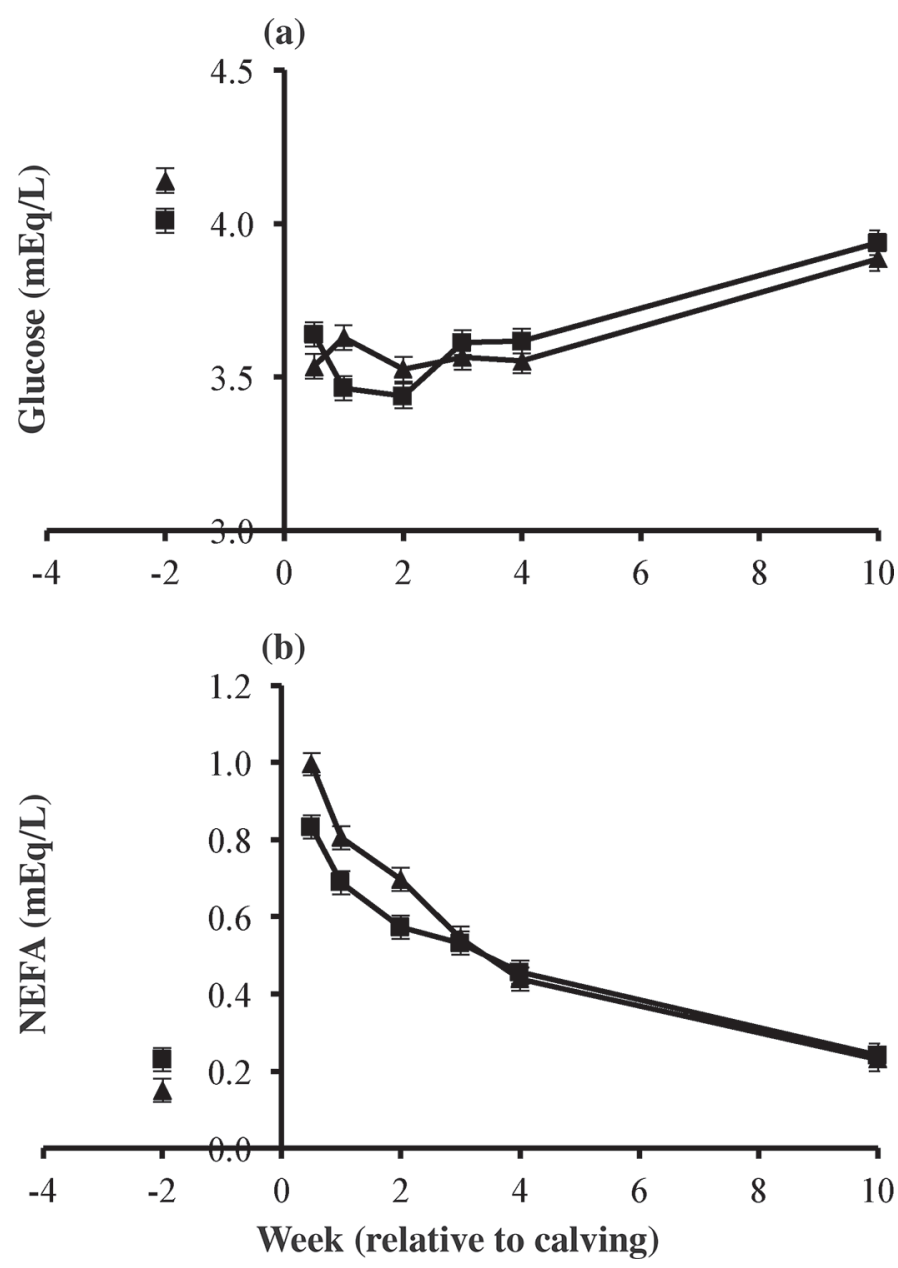

Figure 2. Effects of concentrate supplementation (black boxes, silage; black triangles, silage plus concentrates; error bars represent the SEM) for 4 wk prepartum, on prepartum and postpartum (a) mean weekly serum glucose concentration (postpartum: treatment, SED = $0.07, P=0.895$; time, SED $=0.06, P<0.001$; treatment $\times$ time, SED $=0.10, P=0.071$ ) and (b) mean weekly serum nonesterified fatty acid (NEFA) concentration (postpartum: treatment, $\mathrm{SED}=0.05, P=$ 0.137 ; time, $\mathrm{SED}=0.05, P<0.001$; treatment $\times$ time, $\mathrm{SED}=0.08, P$ $=0.217) . \mathrm{SED}=$ standard error of the differences of means. by the cow's immune response (Sheldon et al., 2008), as discussed below, the fact that the prepartum treatments had no effect on vaginal mucus scores (an assessment of severity of uterine bacterial infection) again helps to explain the similar CL measures with both treatments. Although cow numbers were inadequate to robustly measure fertility performance, the similar uterine health status and postpartum EB with cows on both treatments suggests that large differences in fertility outcomes would not have been expected. In support of this, an on-farm study involving more than 1,200 dairy cows found reproductive performance to be unaffected when cows were offered concentrates either for the entire prepartum period or for the last $4 \mathrm{wk}$ prepartum (Law et al., 2016). A treatment $\times$ parity interaction was present for days to onset of CL activity $(P=0.013)$, with the respective values for cows and heifers being 33 and $26 \mathrm{~d}$ for the SO treatment and 26 and $30 \mathrm{~d}$ for the $\mathrm{S}+\mathrm{C}$ treatment. There was also a treatment $\times$ parity interaction for the maximum progesterone concentration during the first CL $(P=$ 0.003 ), with the respective values for cows and heifers being 20.4 and $29.4 \mathrm{ng} / \mathrm{mL}$ for the $\mathrm{SO}$ treatment and 30.4 and $21.6 \mathrm{ng} / \mathrm{mL}$ for the $\mathrm{S}+\mathrm{C}$ treatment.

\section{Immune Function, Inflammation, and Health}

Although the increased risk of disease during the peripartum period is known (Ingvartsen, 2006), it can be difficult to detect significant treatment differences on binomially distributed clinical disease parameters, without enrolling large numbers of animals on studies (Grummer et al., 2004). As disease status is mediated in part by immune status, this study examined the effect of treatment on the concentrations of negative acute phase protein (APP) albumin, and the innate (neutrophil function) and acquired (IFN- $\gamma$ ) branches of the immune system, as a proxy for health.

Cows on SO had a lower prepartum serum albumin $(P=0.030$; Table 5$)$, and lower postpartum serum albumin $(P=0.006)$ and total protein $(P=0.012)$ concentrations postpartum, compared with those on $\mathrm{S}+\mathrm{C}$. Albumin is considered a negative APP, as blood concentrations decrease during systemic inflammation (Murata et al., 2004) due to the changes in liver activity toward the production of positive APP, such as haptoglobin (Bertoni et al., 2008; Bertoni and Trevisi, 2013). These lower concentrations are suggestive of a higher inflammatory state with cows on SO compared with cows on $\mathrm{S}+\mathrm{C}$, although the absence of an effect of treatment $(P>0.1)$ on the incidence of clinical disease does not support this. For example, the percentage of cows treated for digestive upsets (Table 7), and for uterine health problems, as measured by percentage 
of cows treated with intrauterine antibiotics (Table 7), and the probability of obtaining different vaginal mucus scores at d 7, 14, 21, and 28 of lactation (Table 6) were all unaffected by treatment. Similarly, treatment had no effect $(P>0.1)$ on udder health as measured by the percentage of cows with clinical mastitis and somatic cell scores (Table 3).

Although neutrophil and lymphocyte function is often cited as declining peripartum (Gilbert et al., 1993; Mallard et al., 1998), little evidence was present of a dramatic peripartum decline in neutrophil phagocytosis or oxidative burst in the current study. Although this supports the findings of Llamas Moya et al. (2008) and Little et al. (2016), other measures of neutrophil function, such as chemotaxis or superoxide anion production, were not examined in the current study. In contrast, IFN- $\gamma$ production, which was used to assess lymphocyte functionality, declined at d 3 postpartum compared with wk 2 prepartum, and then increased during the postpartum period $(P<0.001$; Figure $3 \mathrm{a})$ in agreement with others (Lessard et al., 2004; O'Driscoll et al., 2012; Little et al., 2016).

Neutrophils play an important role as the first line of defense against bacterial infections during the transition period (Hussain, 1989; Kimura et al., 1999; Paape et al., 2003). However, the current study provided little evidence that neutrophil function was affected by prepartum nutrition. For example, the phagocytic activity of circulating neutrophils was unaffected by treatment $(P>0.1$; Table 8$)$, whereas only at d 14 postpartum was a tendency present for a higher oxidative burst MFI $(P=0.060$, Table 9$)$ and oxidative burst index $(P=0.078)$ with cows that received additional concentrates during the close-up prepartum period. In contrast, Little et al. (2016) found that cows offered additional concentrates for the entire prepartum period had a higher phagocytic MFI at wk 1 and 2 postpartum compared with those offered silage only, and attributed this to higher serum glucose at wk 1 postpartum, glucose being the preferred fuel for neutrophil activity (Borregaard and Herlin, 1982; Pithon-Curi et al., 2004; Kim et al., 2005). Although serum glucose concentrations were also higher at wk 1 postcalving with $\mathrm{S}+\mathrm{C}$ in the current study (although not at d 3 postcalving), the potential beneficial effects may have been abated due to concurrent higher serum NEFA concentration at this time, which is known to have a detrimental effect on neutrophil function (Hammon et al., 2006; Scalia et al., 2006). The absence of an effect of treatment on glucose concentration at d 3 postpartum may also have contributed to absence of an effect on neutrophil function at d 7. Similarly, in the current study no evidence was observed that peripartum lymphocyte function, as evaluated by IFN- $\gamma$ production, was affected by pre-

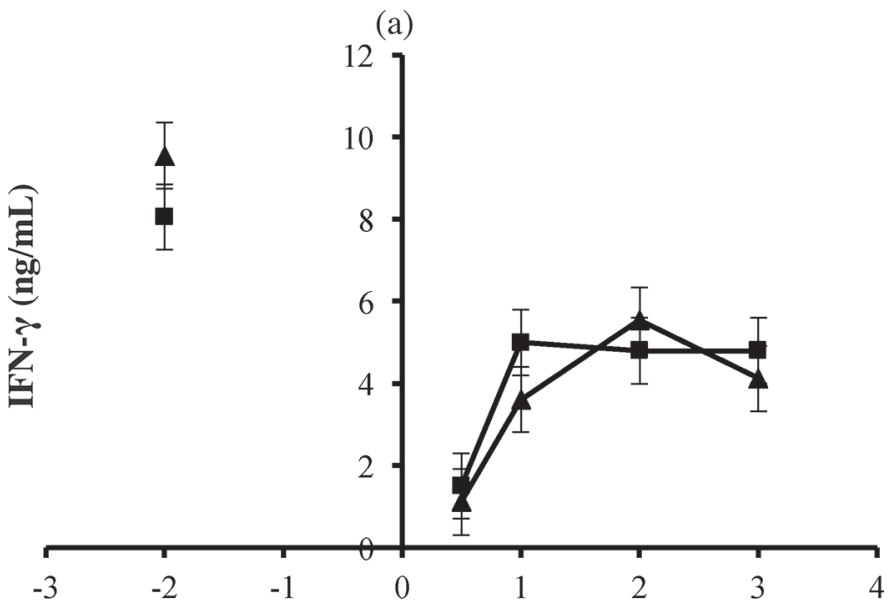

(b)

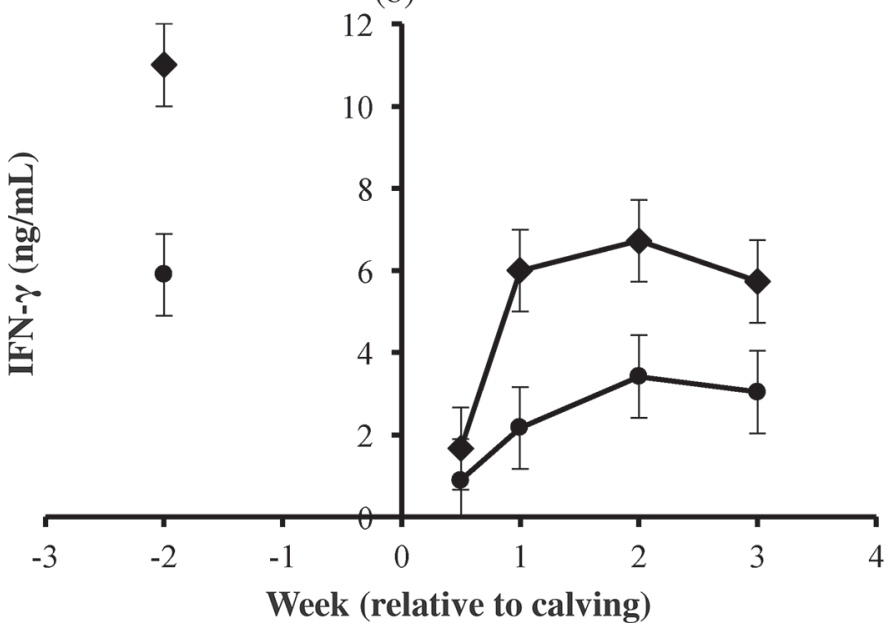

Figure 3. Effects of (a) concentrate supplementation (black boxes, silage only, black triangles, silage plus concentrates; error bars represent the SEM) for $4 \mathrm{wk}$ prepartum, on prepartum and postpartum mean IFN- $\gamma$ production of whole blood due to pokeweed mitogen stimulation (prepartum: treatment, $\mathrm{SED}=2.04, P=0.610$; postpartum: treatment, $\mathrm{SED}=0.87, P=0.619$; time, $\mathrm{SED}=0.97, P<0.001$ treatment $\times$ time, SED $=1.44, P=0.721$ ), and (b) parity (black diamonds, multiparous; black circles, primiparous; error bars represent the SEM) on the mean IFN- $\gamma$ production of whole blood due to pokeweed mitogen stimulation (prepartum: parity, SED $=2.13, P=0.074$ postpartum: parity, $\mathrm{SED}=0.87, P=0.004$; time, $\mathrm{SED}=0.97, P<$ 0.001 ; parity $\times$ time, SED $=1.44, P=0.296)$. SED $=$ standard error of the differences of means.

partum diets, in agreement with Little et al. (2016). In contrast, Stabel et al. (2003) demonstrated that increasing peripartum energy intakes increased postpartum lymphocyte IgG production in diseased cows.

Thus the findings of the current study provide no evidence to suggest that concentrate supplementation during the $4 \mathrm{wk}$ prepartum had a positive effect on neutrophil or lymphocyte function. This again was reflected in the absence of an effect of treatment on SCS, the incidence of clinical mastitis, the percentage of cows 
treated with intrauterine antibiotics, and on vaginal mucus scores. The absence of an effect of prepartum diets on uterine health agrees with Roche et al. (2015), and is an important finding as the ability to resolve uterine infection postpartum is known to have a major effect on fertility outcomes (Walsh et al., 2011).

Whereas no significant interactions $(P<0.05)$ were present between treatment and parity for any of the values presented in Tables 8 and 9, relatively little information is available in the literature on differences in immune function between primiparous and multiparous cows in early lactation. As such, both the main effects of treatment and parity are presented in these tables. In the current study, multiparous cows had a lower MFI of phagocytic neutrophils and lower phagocytic index at $\mathrm{d} 14(P=0.003$ and $P=0.038$, respectively $)$ prepartum and $\mathrm{d} 3(P=0.004$ and $P=0.004$, respectively) and $7(P=0.003$ and $P=0.003$, respectively $)$ postpartum (Table 8 ); a lower percentage of oxidative burst neutrophils at d $3(P=0.021), 7(P=0.061)$, and $21(P=0.012)$ postpartum; lower MFI of oxidative burst neutrophils at $\mathrm{d} 14$ prepartum $(P=0.076)$ and $\mathrm{d}$ $7(P=0.033), 14(P=0.045)$, and $21(P=0.009)$ postpartum; and lower oxidative burst index at d $3(P=$ $0.063), 7(P=0.072)$, and $21(P=0.011)$ postpartum, compared with primiparous cows (Table 9 ). A tendency was observed for a treatment by parity interaction for percentage of oxidative burst neutrophils at $\mathrm{d} 21$ postpartum (Table 9). This finding of lower measures of neutrophil function in multiparous cows compared with primiparous cows supports previous studies, where neutrophils from multiparous cows had lower superoxide anion production (Gilbert et al., 1993) and lower mean oxidative burst activity (Llamas Moya et al., 2008), compared with those from primiparous cows. However, with regard to acquired immune function in the current study, multiparous cows tended to have a higher $(P=$ $0.074)$ IFN- $\gamma$ production prepartum, and had a higher $(P=0.004)$ IFN- $\gamma$ production postpartum (Figure $3 b)$, compared with primiparous cows. Increased IFN- $\gamma$ production is associated with a heightened immune surveillance and function during infection (Schroder et al., 2004) and increased resistance to infectious diseases (Kehrli and Harp, 2001; Nonnecke et al., 2003). This finding of higher production of lymphocyte cytokines after stimulation in multiparous cows compared with primiparous cows agrees with others (Lessard et al., 2004; O'Driscoll et al., 2012). These findings suggest that during the transition period, multiparous cows have a greater decrease in cellular immunity but a lesser decrease in humoral immunity, compared with primiparous cows. This may have increased negative implications for disease in multiparous cows, as the main infectious challenge during the transition period

Table 9. Effects of concentrate supplementation for $4 \mathrm{wk}$ prepartum, and parity, on the mean percentage of oxidative burst neutrophils, the mean fluorescence intensity (MFI) of oxidative burst neutrophils, and the mean oxidative burst index of neutrophils at d 14 prepartum and d $3,7,14$, and 21 postpartum

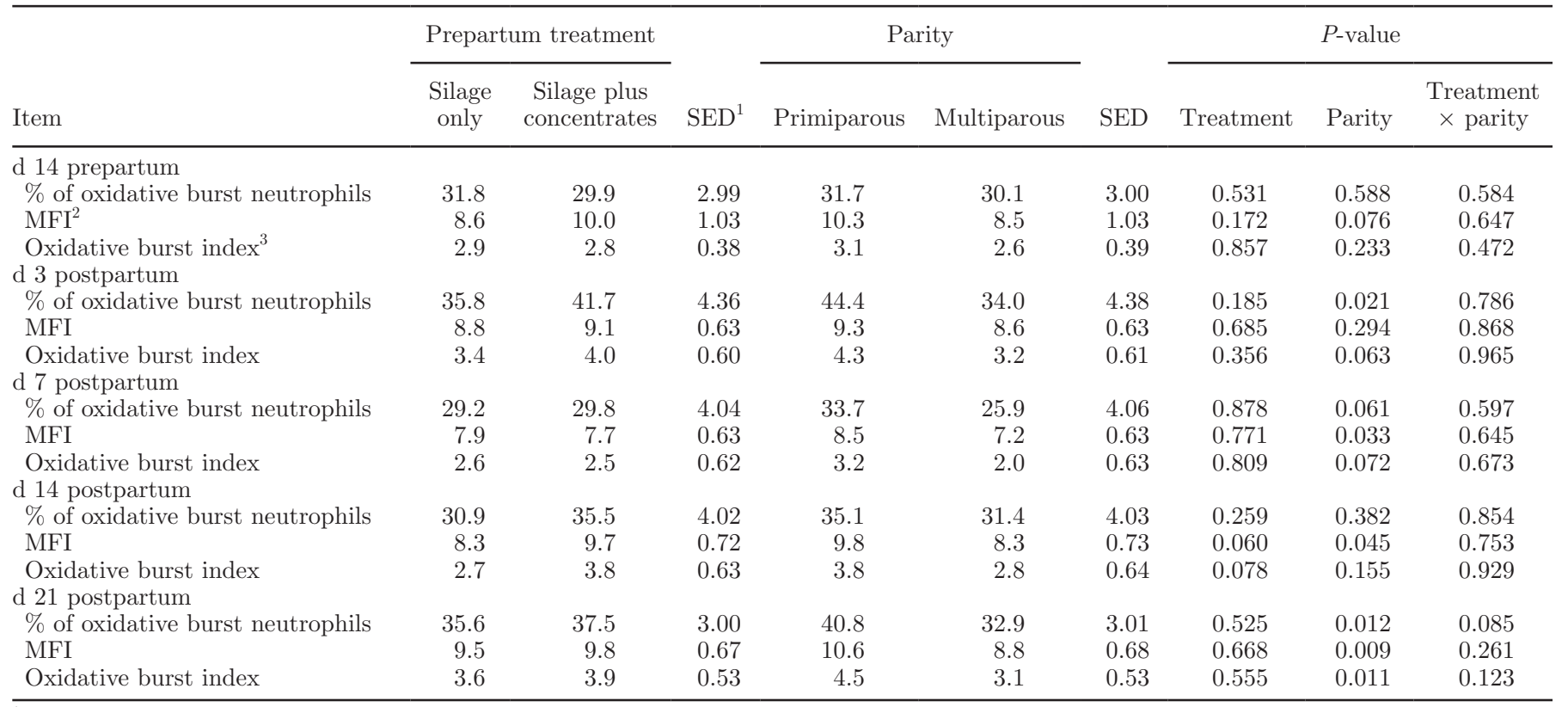

${ }^{1} \mathrm{SED}=$ standard error of the difference.

${ }^{2} \mathrm{MFI}(\times 1,000)$.

${ }^{3}$ Oxidative burst index $=[(\%$ of oxidative burst neutrophils $) \times(\mathrm{MFI})] / 100$. 
comes from bacteria, resulting in diseases such as mastitis (Paape et al., 2003) and metritis (Hussain, 1989).

\section{CONCLUSIONS}

This study demonstrated that when Holstein Friesian cows were offered concentrates in addition to a medium-quality grass silage diet for 4 wk prepartum, they experienced a significantly larger BW and BCS gain prepartum, although the latter was biologically small. Offering additional concentrates prepartum had no effect on postpartum DMI, BW, BCS, milk yield, milk composition, EB, serum NEFA or BHB concentrations, measures of neutrophil and lymphocyte function, cow health, or CL function. This study demonstrated that for cows with a BCS of 2.8 (1 to 5 scale) at drying off, few beneficial effects arose from offering concentrates for the last 4 wk prepartum.

\section{ACKNOWLEDGMENTS}

This study was co-funded by the Department of Agriculture and Rural Development in Northern Ireland and by AgriSearch (farmer levy). Thanks are due to the Dairy Unit staff at the Agri-Food and Biosciences Institute (AFBI) Hillsborough for care of the experimental animals and for assisting with experimental measurements, the laboratory staff in AFBI Hillsborough for undertaking milk and feed analysis, and to the staff in AFBI Veterinary Sciences Division for assisting with immune function analysis. Mark Little acknowledges the receipt of a $\mathrm{PhD}$ studentship from AgriSearch (Hillsborough, Northern Ireland).

\section{REFERENCES}

Agnew, R. E., T. Yan, J. France, E. Kebreab, and C. Thomas. 2004 Energy requirement and Supply. Pages 11-20 in Feed into Milk. A New Applied Feeding System for Dairy Cows. 1st ed. Nottingham University Press, Nottingham, UK.

Allen, M. S. 2000. Effects of diet on short-term regulation of feed intake by lactating dairy cattle. J. Dairy Sci. 83:1598-1624.

Andersen, J. B., J. Sehested, and K. L. Ingvartsen. 1999. Effect of dry cow feeding strategy on rumen $\mathrm{pH}$, concentration of volatile fatty acids and rumen epithelium development. Acta Agric. Scand. Anim. Sci. 49:149-155.

Bertoni, G., and E. Trevisi. 2013. Use of the liver activity index and other metabolic variables in the assessment of metabolic health in dairy herds. Vet. Clin. North Am. Food Anim. Pract. 29:413-431.

Bertoni, G., E. Trevisi, X. Han, and M. Bionaz. 2008. Effects of inflammatory conditions on liver activity in puerperium period and consequences for performance in dairy cows. J. Dairy Sci. 91:33003310 .

Borregaard, N., and T. Herlin. 1982. Energy metabolism of human neutrophils during phagocytosis. J. Clin. Invest. 70:550-557.

Broster, W. H., and V. J. Broster. 1998. Body score of dairy cows. J. Dairy Res. 65:155-173.

Butler, W. R. 2003. Energy balance relationships with follicular development, ovulation and fertility in postpartum dairy cows. Livest. Prod. Sci. 83:211-218.
Cameron, R. E. B., P. B. Dyk, T. H. Herdt, J. B. Kaneene, R. Miller, H. F. Bucholtz, J. S. Liesman, M. J. Vandehaar, and R. S. Emery. 1998. Dry cow diet, management, and energy balance as risk factors for displaced abomasum in high producing dairy herds. J. Dairy Sci. 81:132-139.

Cushnahan, A., and F. J. Gordon. 1995. The effects of grass preservation on intake, apparent digestibility and rumen degradation characteristics. Anim. Sci. 60:429-438.

Dirksen, G. U., H. G. Liebich, and E. Mayer. 1985. Adaptive changes of the ruminal mucosa and their functional and clinical significance. Bovine Practitioner 20:116-120.

Dong, L. F., C. P. Ferris, D. A. McDowell, and T. Yan. 2015. Effects of diet forage proportion on maintenance energy requirement and the efficiency of metabolizable energy use for lactation by lactating dairy cows. J. Dairy Sci. 98:8846-8855.

Drackley, J. K. 1999. Biology of dairy cows during the transition period: The final frontier? J. Dairy Sci. 82:2259-2273.

Drackley, J. K., R. L. Wallace, D. Graugnard, J. Vasquez, B. F. Richards, and J. J. Loor. 2014. Visceral adipose tissue mass in nonlactating dairy cows fed diets differing in energy density. J. Dairy Sci. $97: 3420-3430$

Dunn, A., A. Ashfield, B. Earley, M. Welsh, A. Gordon, M. McGee, and S. J. Morrison. 2016. Effect of colostrum supplementation during the dry period on colostrum quality and effect of colostrum feeding regimen on passive transfer of immunity, calf health, and performance. J. Dairy Sci. 100:357-370.

Edmonson, A. J., I. J. Lean, L. D. Weaver, T. Farver, and G. Webster 1989. A body condition scoring chart for Holstein dairy cows. J. Dairy Sci. 72:68-78.

Farm Animal Welfare Council. 1997. Report on the welfare of dairy cattle. Ministry of Agriculture, Fisheries and Food, Tolworth/Surbiton, Surrey, UK.

Finneran, E., P. Crosson, P. O'Kiely, L. Shalloo, D. Forristal, and M. Wallace. 2012. Stochastic simulation of the cost of home-produced feeds for ruminant livestock systems. J. Agric. Sci. 150:123-139.

Flipot, P. M., G. L. Roy, and J. J. Dufour. 1988. Effect of peripartum energy concentration on production performance of Holstein cows. J. Dairy Sci. 71:1840-1850.

Galvão, K. N., M. J. B. F. Flaminio, S. B. Brittin, R. Sper, M. Fraga, L. Caixeta, A. Ricci, C. L. Guard, W. R. Butler, and R. O. Gilbert. 2010. Association between uterine disease and indicators of neutrophil and systemic energy status in lactating Holstein cows. J. Dairy Sci. 93:2926-2937.

Gilbert, R. O., Y. T. Gröhn, P. M. Miller, and D. J. Hoffman. 1993. Effect of parity on periparturient neutrophil function in dairy cows. Vet. Immunol. Immunopathol. 36:75-82.

Graugnard, D. E., M. Bionaz, E. Trevisi, K. M. Moyes, J. L. SalakJohnson, R. L. Wallace, J. K. Drackley, G. Bertoni, and J. J. Loor. 2012. Blood immunometabolic indices and polymorphonuclear neutrophil function in peripartum dairy cows are altered by level of dietary energy prepartum. J. Dairy Sci. 95:1749-1758.

Grummer, R. R. 1995. Impact of changes in organic nutrient metabolism on feeding the transition dairy cow. J. Anim. Sci. 73:28202833.

Grummer, R. R., D. G. Mashek, and A. Hayirli. 2004. Dry matter intake and energy balance in the transition period. Vet. Clin. North Am. Food Anim. Pract. 20:447-470.

Hammon, D. S., I. M. Evjen, T. R. Dhiman, J. P. Goff, and J. L. Walters. 2006. Neutrophil function and energy status in Holstein cows with uterine health disorders. Vet. Immunol. Immunopathol. $113: 21-29$.

Hayirli, A., R. R. Grummer, E. V. Nordheim, and P. M. Crump. 2002. Animal and dietary factors affecting feed intake during the prefresh transition period in Holsteins. J. Dairy Sci. 85:3430-3443.

Hayirli, A., D. H. Keisler, L. Doepel, and H. Petit. 2011. Peripartum responses of dairy cows to prepartal feeding level and dietary fatty acid source. J. Dairy Sci. 94:917-930.

Hoeben, D., R. Heyneman, and C. Burvenich. 1997. Elevated levels of $\beta$-hydroxybutyric acid in periparturient cows and in vitro effect on respiratory burst activity of bovine neutrophils. Vet. Immunol Immunopathol. 58:165-170. 
Holcomb, C. S., H. H. Van Horn, H. H. Head, M. B. Hall, and C. J. Wilcox. 2001. Effects of prepartum dry matter intake and forage percentage on postpartum performance of lactating dairy cows1. J. Dairy Sci. 84:2051-2058.

Hussain, A. M. 1989. Bovine uterine defense mechanisms: A review. J. Vet. Med. B 36:641-651.

Ingvartsen, K. L. 2006. Feeding- and management-related diseases in the transition cow: Physiological adaptations around calving and strategies to reduce feeding-related diseases. Anim. Feed Sci. Technol. 126:175-213.

Ingvartsen. K. L., and K. Moyes. 2013. Nutrition, immune function and health of dairy cattle. Animal 7(Suppl. 1):112-122.

Janovick, N. A., and J. K. Drackley. 2010. Prepartum dietary management of energy intake affects postpartum intake and lactation performance by primiparous and multiparous Holstein cows. J. Dairy Sci. 93:3086-3102.

Kaneene, J. B., R. Miller, T. H. Herdt, and J. C. Gardiner. 1997. The association of serum nonesterified fatty acids and cholesterol, management and feeding practices with peripartum disease in dairy cows. Prev. Vet. Med. 31:59-72.

Keady, T. W. J., C. S. Mayne, D. A. Fitzpatrick, and M. A. McCoy. 2001. Effect of concentrate feed level in late gestation on subsequent milk yield, milk composition, and fertility of dairy cows. J. Dairy Sci. 84:1468-1479.

Kehrli, M. E. Jr., and J. A. Harp. 2001. Immunity in the mammary gland. Vet. Clin. North Am. Food Anim. Pract. 17:495-516.

Kim, I.-H., K.-J. Na, and M.-P. Yang. 2005. Immune responses during the peripartum period in dairy cows with postpartum endometritis. J. Reprod. Dev. 51:757-764.

Kimura, K., J. P. Goff, and M. E. Kehrli Jr.. 1999. Effects of the presence of the mammary gland on expression of neutrophil adhesion molecules and myeloperoxidase activity in periparturient dairy cows. J. Dairy Sci. 82:2385-2392.

Law, R. A., M. Romero Oiartzun, A. Brown, A. W. Gordon, A. F. Carson, and C. P. Ferris. 2016. The effects of offering concentrates during the dry period on dairy cow performance. Page 371 in Proc. 67th Annual Meeting of the European Federation of Animal Science. Wageningen Academic Publishers, Wageningen, the Netherlands.

Law, R. A., F. J. Young, D. C. Patterson, D. J. Kilpatrick, A. R. G. Wylie, K. L. Ingvarsten, A. Hameleers, M. A. McCoy, C. S. Mayne, and C. Ferris. 2011. Effect of precalving and postcalving dietary energy level on performance and blood metabolite concentrations of dairy cows throughout lactation. J. Dairy Sci. 94:808-823.

Lessard, M., N. Gagnon, D. L. Godson, and H. V. Petit. 2004. Influence of parturition and diets enriched in n- 3 or n- 6 polyunsaturated fatty acids on immune response of dairy cows during the transition period. J. Dairy Sci. 87:2197-2210.

Little, M. W., N. E. O'Connell, M. D. Welsh, J. Barley, K. G. Meade, and C. P. Ferris. 2016. Prepartum concentrate supplementation of a diet based on medium-quality grass silage: Effects on performance, health, fertility, metabolic function, and immune function of low body condition score cows. J. Dairy Sci. 99:7102-7122.

Llamas Moya, S., M. Alonso Gómez, L. A. Boyle, J. F. Mee, B. O'Brien, and S. Arkins. 2008. Effects of milking frequency on phagocytosis and oxidative burst activity of phagocytes from primiparous and multiparous dairy cows during early lactation. J. Dairy Sci. 91:587-595.

Mallard, B. A., J. C. Dekkers, M. J. Ireland, K. E. Leslie, S. Sharif, C. Lacey Vankampen, L. Wagter, and B. N. Wilkie. 1998. Alteration in immune responsiveness during the peripartum period and its ramification on dairy cow and calf health. J. Dairy Sci. 81:585-595.

Mann, S., F. A. L. Yepes, T. R. Overton, J. J. Wakshlag, A. L. Lock, C. M. Ryan, and D. V. Nydam. 2015. Dry period plane of energy: Effects on feed intake, energy balance, milk production, and composition in transition dairy cows. J. Dairy Sci. 98:3366-3382.

McCarthy, M. M., S. Mann, D. V. Nydam, T. R. Overton, and J. A. A McArt. 2015. Short communication: Concentrations of nonesterified fatty acids and $\beta$-hydroxybutyrate in dairy cows are not well correlated during the transition period. J. Dairy Sci. 98:6284-6290.
McNamara, S., J. J. Murphy, M. Rath, and F. P. O'Mara. 2003a. Effects of different transition diets on energy balance, blood metabolites and reproductive performance in dairy cows. Livest. Prod. Sci. 84:195-206.

McNamara, S., F. P. O'Mara, M. Rath, and J. J. Murphy. 2003b. Effects of different transition diets on dry matter intake, milk production, and milk composition in dairy cows. J. Dairy Sci. 86:2397-2408.

Moyes, K. M., T. Larsen, N. C. Friggens, J. K. Drackley, and K. L. Ingvartsen. 2009. Identification of potential markers in blood for the development of subclinical and clinical mastitis in dairy cattle at parturition and during early lactation. J. Dairy Sci. 92:5419-5428.

Mulligan, F. J., and M. L. Doherty. 2008. Production diseases of the transition cow. Vet. J. 176:3-9.

Murata, H., N. Shimada, and M. Yoshioka. 2004. Current research on acute phase proteins in veterinary diagnosis: An overview. Vet. J. 168:28-40.

Nonnecke, B. J., K. Kimura, J. P. Goff, and M. E. Kehrli Jr.. 2003. Effects of the mammary gland on functional capacities of blood mononuclear leukocyte populations from periparturient cows. J. Dairy Sci. 86:2359-2368.

Nowak, W., R. Mikula, A. Zachwieja, K. Paczynska, E. Pecka, K. Drzazga, and P. Slosarz. 2012. The impact of cow nutrition in the dry period on colostrum quality and immune status of calves. Pol. J. Vet. Sci. 15:77-82.

NRC. 2001. Nutrient Requirements for Dairy Cattle. 7th rev. ed. National Academy Press, Washington, DC.

O’Driscoll, K., G. Olmos, S. Llamas Moya, J. F. Mee, B. Earley, D. Gleeson, B. O'Brien, and L. Boyle. 2012. A reduction in milking frequency and feed allowance improves dairy cow immune status. J. Dairy Sci. 95:1177-1187.

Ospina, P. A., D. V. Nydam, T. Stokol, and T. R. Overton. 2010. Evaluation of nonesterified fatty acids and $\beta$-hydroxybutyrate in transition dairy cattle in the northeastern United States: Critical thresholds for prediction of clinical diseases. J. Dairy Sci. 93:546554

Otter, A. 2013. Diagnostic blood biochemistry and haematology in cattle. In Practice 35:7-16.

Paape, M. J., D. D. Bannerman, X. Zhao, and J. W. Lee. 2003. The bovine neutrophil: Structure and function in blood and milk. Vet. Res. 34:597-627.

Park, R. S., R. E. Agnew, F. J. Gordon, and R. W. J. Steen. 1998. The use of near infrared reflectance spectroscopy (NIRS) on undried samples of grass silage to predict chemical composition and digestibility parameters. Anim. Feed Sci. Technol. 72:155-167.

Pithon-Curi, T. C., M. P. De Melo, and R. Curi. 2004. Glucose and glutamine utilization by rat lymphocytes, monocytes and neutrophils in culture: A comparative study. Cell Biochem. Funct. 22:321-326.

Porter, M. G., and R. S. Murray. 2001. The volatility of components of grass silage on oven drying and the inter-relationship between drymatter content estimated by different analytical methods. Grass Forage Sci. 56:405-411

Rabelo, E., R. L. Rezende, S. J. Bertics, and R. R. Grummer. 2003. Effects of transition diets varying in dietary energy density on lactation performance and ruminal parameters of dairy cows. J. Dairy Sci. 86:916-925

Roche, J. R., A. W. Bell, T. R. Overton, and J. J. Loor. 2013. Nutritional management of the transition cow in the 21st century-A paradigm shift in thinking. Anim. Reprod. Sci. 53:1000-1023.

Roche, J. R., N. C. Friggens, J. K. Kay, M. W. Fisher, K. J. Stafford, and D. P. Berry. 2009. Invited review: Body condition score and its association with dairy cow productivity, health, and welfare. J. Dairy Sci. 92:5769-5801.

Roche, J. R., S. Meier, A. Heiser, M. D. Mitchell, C. G. Walker, M. A Crookenden, M. V. Riboni, J. J. Loor, and J. K. Kay. 2015. Effects of precalving body condition score and prepartum feeding level on production, reproduction, and health parameters in pasture-based transition dairy cows. J. Dairy Sci. 98:7164-7182.

Sauer, M. J., J. A. Foulkes, A. Worsfold, and B. A. Morris. 1986. Use of progesterone 11-glucuronide-alkaline phosphatase conjugate in 
a sensitive microtitre-plate enzymeimmunoassay of progesterone in milk and its application to pregnancy testing in dairy cattle. J. Reprod. Fertil. 76:375-391.

Scalia, D., N. Lacetera, U. Bernabucci, K. Demeyere, L. Duchateau, and C. Burvenich. 2006. In vitro effects of nonesterified fatty acids on bovine neutrophils oxidative burst and viability. J. Dairy Sci. $89: 147-154$.

Schroder, K., P. J. Hertzog, T. Ravasi, and D. A. Hume. 2004. Interferon- $\gamma$ : An overview of signals, mechanisms and functions. J. Leukoc. Biol. 75:163-189.

Sheldon, I. M., E. J. Williams, A. N. A. Miller, D. M. Nash, and S. Herath. 2008. Uterine diseases in cattle after parturition. Vet. J. $176: 115-121$

Stabel, J. R., J. P. Goff, and K. Kimura. 2003. Effects of supplementa energy on metabolic and immune measurements in periparturient dairy cows with Johne's disease. J. Dairy Sci. 86:3527-3535.

Steen, R. W. J. 1989. A comparison of soya-bean, sunflower and fish meals as protein supplements for yearling cattle offered grass silage-based diets. Anim. Sci. 48:81-89.

Ster, C., M. C. Loiselle, and P. Lacasse. 2012. Effect of postcalving serum nonesterified fatty acids concentration on the functionality of bovine immune cells. J. Dairy Sci. 95:708-717.
Suriyasathaporn, W., C. Heuer, E. N. Noordhuizen-Stassen, and Y. H. Schukken. 2000. Hyperketonemia and the impairment of udder defense: A review. Vet. Res. 31:397-412.

United Kingdom Animals (Scientific Procedures) Act. 1986. Accessed Mar. 12, 2017. http://www.legislation.gov.uk/ukpga/1986/14/ contents.

Vickers, L. A., D. M. Weary, D. M. Veira, and M. A. G. von Keyserlingk. 2013. Feeding a higher forage diet prepartum decreases incidences of subclinical ketosis in transition dairy cows. J. Anim. Sci. 91:886-894.

Walsh, S. W., E. J. Williams, and A. C. O. Evans. 2011. A review of the causes of poor fertility in high milk producing dairy cows. Anim. Reprod. Sci. 123:127-138.

Williams, E. J., D. P. Fischer, D. U. Pfeiffer, G. C. W. England, D. E. Noakes, H. Dobson, and I. M. Sheldon. 2005. Clinical evaluation of postpartum vaginal mucus reflects uterine bacterial infection and the immune response in cattle. Theriogenology 63:102-117.

Zhang, Q., H. Su, F. Wang, Z. Cao, and S. Li. 2015. Effects of energy density in close-up diets and postpartum supplementation of extruded full-fat soybean on lactation performance and metabolic and hormonal status of dairy cows. J. Dairy Sci.98:7115-7130. 